\title{
Hydrogeochemistry and Quality Assessment for the Groundwater of the Nubian Sandstone Aquifer of the Bahariya Oasis, Western Desert, Egypt
}

\author{
Himida, I.H. ${ }^{1}$ Holial, H.M. ${ }^{2}$, Shaaban, M.N. ${ }^{2}$, El-Fiky, A.A. ${ }^{3}$, Abd El-Latif, R.M. ${ }^{1}$
}

\begin{abstract}
Groundwater is considered as one of the most important natural resources, on which a complete dependence for all human consumption, industrial and agricultural activities in El-Bahariya Oasis. Unfortunately, the increased reliance on groundwater resources without any scientific pre-plans has caused some negative hydrogeological impacts such as: rapid decline in groundwater potentiometric levels and groundwater salinization. The hydrogeochemical aspects of El-Bahariya Oasis are thoroughly evaluated in the present work based on chemical analysis of 59 groundwater samples, representing the main aquifer system (Nubian Sandstone Aquifer). Most of water wells drilled in the study area range from 600 to $1200 \mathrm{~m}$ in depth. The groundwaters from the Nubian Sandstone Aquifer in El-Bahariya Oasis have mixed types of mineralization, i.e., pure meteoric water that vertically infiltrated and settled in the aquifer materials during the past Pluvial times and those affected through groundwater flow by relics of marine water. It has been found that the majority of the groundwater samples of the Nubian Sandstone Aquifer of El-Bahariya Oasis is suitable for drinking, domestic uses, irrigation, livestock and poultry and some industrial purposes.
\end{abstract}

Keywords: Nubian Sandstone Aquifer- Bahariya Oasis - Hydrogeochemistry -Quality assessment- Egypt.

\section{INTRODUCTION}

El-Bahariya Oasis is a natural depression approximately located in the heart of the Western Desert of Egypt (Fig.1). It is located between latitudes $27^{\circ} 48^{-}$ and $28^{\circ} 30^{\circ} \mathrm{N}$ and longitudes $28^{\circ} 35^{\circ}$ and $29^{\circ} 10^{\circ} \mathrm{E}$, about $370 \mathrm{~km}$ southwest of Cairo and around $190 \mathrm{~km}$ west of Samalut town in the Nile Valley. It occupies an area of about $1800 \mathrm{Km}^{2}$.

The groundwater-bearing horizons in the investigated area follow two aquifer systems. These are, from top to bottom: a) The Post-Nubian Sandstone Aquifer System, which occurs to the north of latitude $26^{0}$ in the Western Desert of Egypt (CEDARE, 2001). It is composed of marine sediments, mainly consist of clay, marl and limestone, overlain by continental clastic sediments, which exhibit noticeable facies variation in the northern parts of Egypt to pass laterally into carbonate facies. This sequence ranges in age from Late Cenomanian to Recent. b) The Nubian Sandstone

${ }^{1}$ Dept of Hydrology, Desert Research Center, Egypt

${ }^{2}$ Dept of Geology, Faculty of Science, Alexandria University, Egypt

${ }^{3}$ Dept of Environmental, Faculty of Science, Alexandria

University, Egypt

Received December 08, 2011, Accepted December31, 2011.
Aquifer System, which represents the main waterbearing horizon in the study area. It consists of continental clastic sediments, mainly sandstone alternating with shale and clays.

In El-Bahariya Oasis, the extraction of excessive quantities of groundwater has resulted in progressive depletion of the storage (Nubian Sandstone Aquifer) and continual decline of potentiometric level (Abd El-Latif, 2007). This leads to increasing cost of pumping even with a reduction in well yield. Other associated adverse consequences would be deterioration of groundwater quality. Accordingly, a major concern in managing groundwater resources is whether or not water quality variables have changed over time or space.

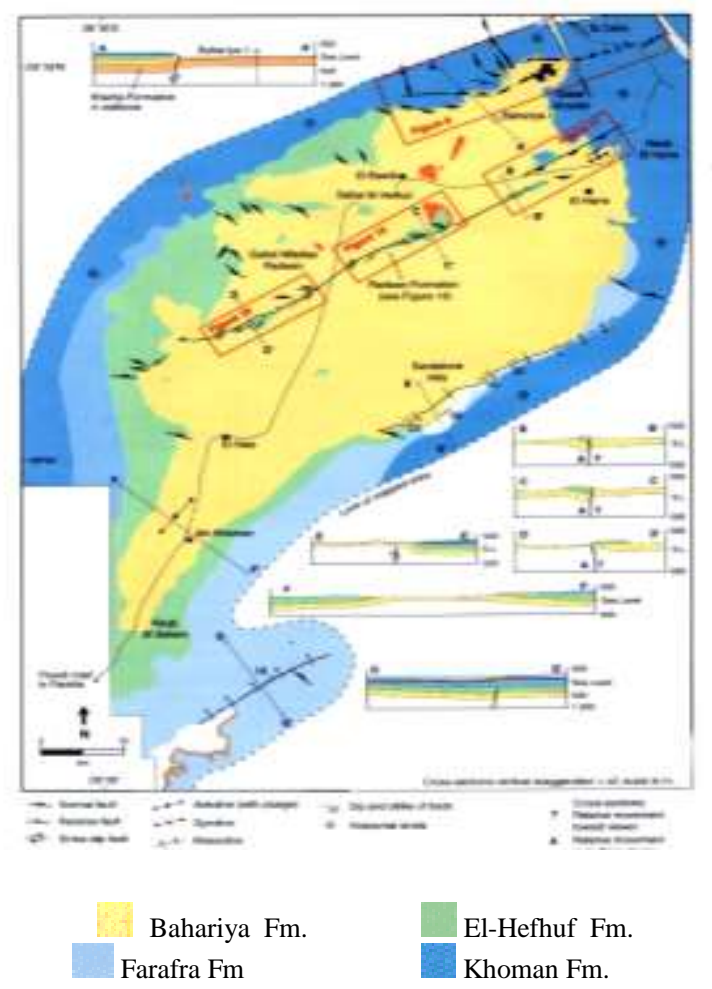

Fig.1. Simplified geological mapand crosssections of El-BahariyaOasis (after Moustafa et al., 2003) 


\section{MATERIALS AND METHODS}

The collected groundwater samples were chemically analyzed for the major cations $\left(\mathrm{Ca}^{++}, \mathrm{Mg}^{++}, \mathrm{Na}^{+}\right.$and $\left.\mathrm{K}^{+}\right)$ and anions $\left(\mathrm{HCO}_{3}^{-}, \mathrm{SO}_{4}^{--}, \mathrm{Cl}^{-}\right)$and minor $\left(\mathrm{Br}^{-}, \mathrm{I}^{-}, \mathrm{SiO}_{2}\right.$ and $\mathrm{B})$ and trace elements $(\mathrm{Al}, \mathrm{Cd}, \mathrm{Co}, \mathrm{Cr}, \mathrm{Cu}, \mathrm{Zn}, \mathrm{Fe}$, $\mathrm{Mn}, \mathrm{Ni}, \mathrm{Pb}$, and $\mathrm{Sr}$ ), in order to determine the hydrochemical facies and assessment of groundwater quality (Table 1).

The procedures of Rainwater and Thatcher (1960) were applied on the collected groundwater samples. Temperature $\left({ }^{\circ} \mathrm{C}\right), \mathrm{pH}$ and electrical conductivity (EC, $\mu \mathrm{S} / \mathrm{cm}$ ) of the groundwater samples were measured in the field at the time of collection. Each water sample was stored in two polyethylene bottles. Water in one of the bottles was acidified upon collection with ultrapure concentrated nitric acid $\left(\mathrm{HNO}_{3}\right)$ to $\mathrm{pH}<2$. Acidification stops most bacterial growth, blocks oxidation reactions and prevents adsorption or precipitation of cations. Whereas, water in the second bottle was kept unacidified for $\mathrm{Cl}^{-}, \mathrm{SO}_{4}^{--}$and alkalinity determinations. The samples were analyzed for the cations $\left(\mathrm{Ca}^{++}, \mathrm{Mg}^{++}\right.$, $\mathrm{Na}^{+}$and $\left.\mathrm{K}^{+}\right)$and the anions $\left(\mathrm{HCO}_{3}^{-}, \mathrm{SO}_{4}^{--}\right.$and $\left.\mathrm{Cl}^{-}\right)$. Calcium and Magnesium were determined by titration against a standard EDTA solution by complexometric method using murexide and eriochrome black-T indicators in presence of suitable buffer, respectively. Sodium and Potassium $\left(\mathrm{Na}^{+}\right.$and $\left.\mathrm{K}^{+}\right)$were determined using a flamephotometer Jenway Model pep7 (UK). Bicarbonate $\left(\mathrm{HCO}_{3}{ }^{-}\right)$was determined titrimetrically against sulphuric acid by neutralization method. Sulfate $\left(\mathrm{SO}_{4}{ }^{--}\right)$was determined by turbidimetric method using UV/Visible Spectrophotometer, Unicam model UV4200 (UK). Chloride $\left(\mathrm{Cl}^{-}\right)$was volumetrically determined against a standard solution of silver nitrate using potassium chromate as indicator. Silica $\left(\mathrm{SiO}_{2}\right)$ was determined by colorimetric method using UV/Visible Spectrophotometer, Unicam model UV4-200 (UK). Bromide $\left(\mathrm{Br}^{-}\right)$was determined by ion selective electrode using Ionometer, Orion-930. Minor and trace elements, which include aluminum (Al), boron (B), cadmium (Cd), cobalt $(\mathrm{Co})$, lead $(\mathrm{Pb})$, chromium $(\mathrm{Cr})$, copper $(\mathrm{Cu})$, zinc $(\mathrm{Zn})$, iron $(\mathrm{Fe})$, manganese $(\mathrm{Mn})$, nickel $(\mathrm{Ni})$ and strontium ( $\mathrm{Sr}$ ) were determined using Atomic Absorption Spectrophotometer, Unicam model Solaar 929. Total dissolved solid (TDS) was calculated from the summation of cations and anions. The accuracy of the analysis can be estimated from the ionic balance (B), which may be expressed, as follows:

$$
\text { B \% }=\frac{\left(\sum_{\text {cations }}-\sum_{\text {anions }}\right)}{\left(\sum_{\text {cations }}+\sum_{\text {anions }}\right)} \times 100
$$

Where cations and anions are expressed as meq/l. Groundwater samples should lie within an errors of \pm $5 \%$. The ionic balance (B) for all the groundwater samples of El-Bahariya Oasis lies within the standard error limit $( \pm 5 \%)$

\section{Hydrogeochemistry}

The groundwater temperature in El-Bahariya Oasis ranges from $22{ }^{\circ} \mathrm{C}$ to $55^{\circ} \mathrm{C}$ with an average temperature of $41{ }^{\circ} \mathrm{C}$, where the highest and lowest temperatures were recorded for samples No.55 and No.38, respectively. Therefore, thermal groundwaters (hot springs) are found in the study area, where the temperature gradient profile is normal. The original reservoir temperature was estimated using Giggenbach (1988)'s geothermometer method (Table 2), as follows:

$$
\begin{aligned}
& \mathrm{T}^{\mathrm{O} C}=\frac{4410}{\left.14-\frac{\log _{C_{k}^{2}}^{2}}{C_{M g}}-273 \quad \text { (in } \mathrm{mg} / \mathrm{l}\right)} \\
& \text { The quotient }\left(\frac{C_{k}^{2}}{C_{M g}}\right) \text { adjusts much faster and to low }
\end{aligned}
$$

temperatures $\left(<100 \quad{ }^{\circ} \mathrm{C}\right)$. From Table (2), the groundwater temperature in the study area is described as normal geothermal gradient not as a result of the effect of the hydrothermal solutions (Abd El-Latif, 2007). Geothermal waters, which are generally accepted to be of meteoric origin, represent groundwaters that have percolated deep into the ground and gained heat through contact with hot rock (Magnusdottir et al., 1992). Most of the groundwater that found in ElBahariya Oasis has $\mathrm{pH}$ ranges from 7.02 to 8.5 (i.e. neutral to slightly alkaline), but seldom to be below 6.5 (Table 1).

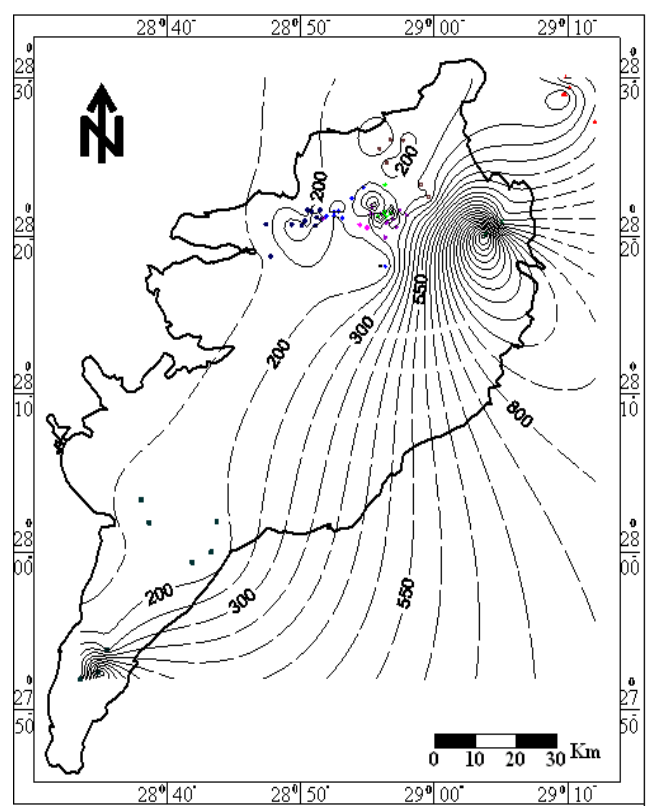

Fig.2. Iso-salinity contour map of El-Bahariya Oasis 
Table 1. Chemistry of groundwater from the Nubian Sandstone Aquifer, Bahariya Oasis ((Abd El-Latif, 2007)

\begin{tabular}{|c|c|c|c|c|c|c|c|c|c|c|c|c|c|c|}
\hline \multirow[t]{2}{*}{ No } & \multirow[b]{2}{*}{ Well name } & \multirow[b]{2}{*}{ pH } & \multirow{2}{*}{$\begin{array}{l}\mathrm{T} \\
{ }^{\circ} \mathrm{C}\end{array}$} & \multirow{2}{*}{$\frac{\text { E.C }}{\mu \mathrm{S} / \mathrm{cm}}$} & \multirow{2}{*}{$\begin{array}{l}\text { TDS } \\
\mathrm{mg} / \mathrm{l}\end{array}$} & \multirow{2}{*}{$\begin{array}{l}\text { T.H. } \\
\mathrm{mg} / \mathrm{l}\end{array}$} & \multicolumn{4}{|c|}{ Cations (mg/l) } & \multicolumn{3}{|c|}{ Anions (mg/l) } & \multirow{2}{*}{$\begin{array}{c}\mathrm{Br} \\
\mathrm{mg} / \mathrm{l}\end{array}$} \\
\hline & & & & & & & $\mathbf{C a}^{++}$ & $\mathbf{M g}^{++}$ & $\mathrm{Na}^{+}$ & $\mathbf{K}^{+}$ & $\mathrm{HCO3}^{-}$ & $\mathrm{SO4}^{--}$ & $\mathrm{Cl}^{-}$ & \\
\hline $\mathbf{1}$ & Ain Halfa & 7.55 & 47 & 282 & 202.86 & 75.0 & 20 & 6.08 & 27 & 18 & 29.55 & 33 & 69.23 & 0.626 \\
\hline 2 & Bawiti drink & 8.08 & 37 & 380 & 273.87 & 95.5 & 20.24 & 10.94 & 32 & 30 & 65.28 & 53 & 62.41 & 0.582 \\
\hline 3 & El-American & 7.55 & 47 & 371 & 230.44 & 72.5 & 14.03 & 9.12 & 37 & 25 & 29.55 & 26 & 89.74 & 0.954 \\
\hline 4 & El-Matar & 7.55 & 47 & 342 & 251.37 & 77.5 & 15.03 & 9.73 & 39 & 25 & 27.82 & 63 & 71.79 & 0.762 \\
\hline 5 & Dehqema & 8.07 & 47 & 312 & 260.76 & 95.0 & 16 & 13.37 & 38 & 20 & 24.34 & 67 & 82.05 & 0.742 \\
\hline 6 & El-Abida & 7.26 & 48 & 276 & 185.34 & 65.0 & 12 & 8.51 & 27 & 18 & 31.29 & 27 & 61.54 & 0.449 \\
\hline 7 & El-Qeles & 8.05 & 44 & 447 & 269.57 & 86.5 & 17.64 & 10.34 & 45 & 27 & 34.77 & 22 & 112.82 & 1.3 \\
\hline 8 & Beshmo & 7.29 & 48 & 287 & 188.45 & 63.5 & 14.83 & 6.44 & 28 & 19 & 26.08 & 30 & 64.10 & 0.565 \\
\hline 9 & Gevara & 7.81 & 43 & 215 & 142.92 & 55.0 & 16 & 3.65 & 18 & 12 & 29.55 & 15 & 48.72 & 0.159 \\
\hline 10 & Mine-4 & 8.45 & 30 & 499 & 414.22 & 125.0 & 28 & 13.37 & 80 & 19 & 62.59 & 101 & 110.26 & 1.19 \\
\hline 11 & Mine-8 & 8.15 & 38 & 399 & 308.34 & 105.0 & 22.04 & 12.16 & 53 & 16 & 57.96 & 60 & 87.18 & 0.971 \\
\hline 12 & Mine-6 & 7.85 & 45 & 282 & 197.38 & 83.0 & 24.05 & 5.59 & 26 & 12 & 34.77 & 36 & 58.97 & 0.488 \\
\hline 13 & Mine-7 & 7.67 & 48 & 274 & 204.68 & 82.5 & 18.04 & 9.12 & 25 & 17 & 29.55 & 47 & 58.97 & 0.401 \\
\hline 14 & Mine-1 & 6.16 & 32 & 708 & 433.46 & 246.0 & 42.08 & 34.29 & 39 & 15 & 54.91 & 161 & 87.18 & 0.797 \\
\hline 15 & Ain Shawer & 8.41 & 32 & 329 & 220.40 & 120.0 & 30.06 & 10.94 & 15 & 15 & 39.99 & 53 & 56.41 & 0.232 \\
\hline 16 & Waled & 7.62 & 51 & 321 & 247.82 & 110.0 & 30 & 8.51 & 29 & 17 & 34.77 & 67 & 61.54 & 0.648 \\
\hline 17 & Meftela & 8.45 & 46 & 350 & 227.23 & 85.0 & 24.05 & 6.08 & 31 & 16 & 56.13 & 35 & 58.97 & 0.808 \\
\hline 18 & Shroey & 7.81 & 46 & 477 & 334.52 & 130.0 & 30 & 13.37 & 47 & 24 & 43.46 & 69 & 107.69 & 1.37 \\
\hline 19 & Dedela & 7.92 & 32 & 242 & 153.12 & 70.0 & 19.04 & 5.47 & 14 & 16 & 27.46 & 25 & 46.15 & 0.154 \\
\hline 20 & Ain Embash & 8.01 & 36 & 313 & 208.44 & 106.0 & 27.45 & 9.12 & 16 & 15 & 41.72 & 53 & 46.15 & 0.203 \\
\hline 21 & El-Ayon & 7.59 & 46 & 421 & 277.48 & 100.0 & 20 & 12.15 & 44 & 23 & 34.77 & 41 & 102.56 & 1.05 \\
\hline 22 & Tabaneia & 8.37 & 37 & 466 & 286.93 & 92.5 & 19.04 & 10.94 & 37 & 29 & 71.28 & 53 & 66.67 & 0.499 \\
\hline 23 & Barakat & 8.3 & 30 & 301 & 178.79 & 85.0 & 24.05 & 6.08 & 14 & 17 & 36.51 & 35 & 46.15 & 0.25 \\
\hline 24 & Mady & 7.17 & 33 & 256 & 156.26 & 76.0 & 12.02 & 11.19 & 14 & 14 & 29.90 & 29 & 46.15 & 0.203 \\
\hline 25 & Ain El Seer & 7.53 & 48 & 346 & 216.78 & 65.5 & 11.02 & 9.24 & 39 & 20 & 32.34 & 18 & 87.18 & 0.926 \\
\hline 26 & Tobela & 7.44 & 42 & 418 & 312.58 & 135.0 & 17.64 & 22.13 & 43 & 22 & 38.25 & 67 & 102.56 & 1.31 \\
\hline 27 & El-Kebier & 8.16 & 41 & 407 & 271.36 & 90.0 & 12.42 & 14.35 & 42 & 23 & 41.49 & 74 & 64.10 & 0.976 \\
\hline 28 & Ain Hamra & 8.47 & 40 & 428 & 257.83 & 85.0 & 17.64 & 9.97 & 43 & 23 & 39.66 & 22 & 102.56 & 1.14 \\
\hline 29 & Maesera & 7.23 & 40 & 274 & 176.47 & 65.0 & 10 & 9.72 & 26 & 17 & 26.08 & 21 & 66.67 & 0.488 \\
\hline 30 & El-Gazaier & 8.26 & 43 & 393 & 246.25 & 88.0 & 13.23 & 13.38 & 40 & 21 & 34.77 & 29 & 94.87 & 0.926 \\
\hline 31 & Segam & 7.36 & 43 & 363 & 262.32 & 101.5 & 19.64 & 12.77 & 36 & 21 & 51.86 & 39 & 82.05 & 0.742 \\
\hline 32 & Qubala East & 7.51 & 46 & 511 & 316 & 122.0 & 21.64 & 16.54 & 50 & 21 & 33.56 & 63 & 110.26 & 0.887 \\
\hline 33 & Qubala West & 7.62 & 47 & 202 & 187.72 & 47.5 & 10.02 & 5.47 & 34 & 16 & 30.51 & 43 & 48.72 & 1.44 \\
\hline 34 & Abu Singo (new) & 7.03 & 42 & 231 & 191.63 & 87.5 & 13.03 & 13.37 & 20 & 14 & 34.77 & 58 & 38.46 & 0.084 \\
\hline 35 & El Ghaba - & 7.46 & 30 & 709 & 483.38 & 239.0 & 57.31 & 23.35 & 53 & 28 & 30.51 & 163.0 & 128.21 & 1.01 \\
\hline 36 & Sidi Ahmed & 7.4 & 33 & 247 & 184.70 & 90.0 & 28 & 4.86 & 14 & 17 & 19.12 & 53 & 48.72 & 0.983 \\
\hline 37 & Mehebes & 6.86 & 31 & 242 & 162.91 & 70.0 & 16 & 7.29 & 18 & 16 & 24.34 & 30 & 51.28 & 0.121 \\
\hline 38 & Tablamon & 7.86 & 22 & 230 & 155.87 & 61.5 & 12 & 9.72 & 15 & 15 & 43.93 & 30 & 35.90 & 0.078 \\
\hline 39 & Ain El-Ezza & 7.55 & 42 & 222 & 161.55 & 70.0 & 13.23 & 11.55 & 20 & 15 & 24.34 & 50 & 46.15 & 0.176 \\
\hline 40 & Ain Qara & 7.85 & 53 & 228 & 180.27 & 80.5 & 16.63 & 24.68 & 20 & 19 & 31.73 & 84 & 61.54 & 0.226 \\
\hline 41 & Khamaan & 7.96 & 38 & 470 & 257.58 & 143.0 & 78.36 & 29.18 & 120 & 59 & 26.08 & 166.0 & 302.56 & 2.85 \\
\hline 42 & Badr Farm & 7.52 & 29 & 1267 & 781.18 & 315.5 & 20.04 & 15.81 & 6 & 33 & 52.15 & 63 & 41.03 & \\
\hline 43 & New (El-Heiz) & 8.52 & 44 & 291 & 231.03 & 115.0 & 16.63 & 8.75 & 44 & 26 & 32.95 & 19 & 107.69 & 0.943 \\
\hline 44 & Aguz West & 7.78 & 43 & 424 & 255.02 & 77.5 & 13.03 & 13.37 & 20 & 14 & 34.77 & 58 & 38.46 & 0.084 \\
\hline 45 & Aguz East & 7.59 & 47 & 254 & 207.73 & 60.0 & 16.03 & 4.86 & 34 & 13 & 33.56 & 55 & 51.28 & 0.247 \\
\hline 46 & El-Magaria & 7.52 & 47 & 300 & 205.12 & 75.0 & 12 & 10.94 & 27 & 21 & 26.08 & 44 & 64.10 & 0.461 \\
\hline 47 & El-Habasi & 8.18 & 35 & 337 & 289.49 & 100.0 & 18 & 13.37 & 34 & 31 & 52.15 & 82 & 58.97 & 0.373 \\
\hline 48 & Mehibes & 7.69 & 43 & 480 & 345 & 140.0 & 40 & 9.72 & 44 & 23 & 43.46 & 72 & 112.82 & 0.964 \\
\hline 49 & Kom Shada & 8.36 & 32 & 772 & 528.07 & 112.0 & 37.88 & 4.26 & 136 & 20 & 34.77 & 87 & 208.16 & 1.53 \\
\hline 50 & Ain Ghard & 7.18 & 28 & 874 & 546.01 & 210.0 & 40.08 & 26.75 & 94 & 23 & 34.77 & 171.0 & 156.41 & 1.35 \\
\hline 51 & Ain El Qasr & 7.52 & 52 & 284 & 221.98 & 100.0 & 20 & 12.15 & 25 & 17 & 31.29 & 55 & 61.54 & 0.384 \\
\hline 52 & Qassa-1 & 7.62 & 45 & 400 & 283.44 & 105.0 & 20 & 13.37 & 39 & 24 & 52.15 & 58 & 76.92 & 0.68 \\
\hline 53 & Qassa-2 & 7.81 & 40 & 425 & 275.65 & 95.0 & 14.03 & 14.59 & 39 & 25 & 67.11 & 39 & 76.92 & 0.578 \\
\hline 54 & Qassa-3 & 7.27 & 52 & 286 & 182.69 & 55.0 & 18 & 2.43 & 29 & 18 & 31.29 & 25 & 58.97 & 0.391 \\
\hline 55 & El-Dolab & 7.02 & 55 & 268 & 179.57 & 65.0 & 16 & 6.08 & 27 & 14 & 26.08 & 34 & 56.41 & 0.461 \\
\hline 56 & Qassa-4 & 7.33 & 45 & 338 & 238.70 & 83.5 & 14.43 & 11.55 & 35 & 21 & 41.49 & 46 & 69.23 & 0.966 \\
\hline 57 & Gemaha (new) & 8.23 & 40 & 388 & 265.71 & 117.5 & 23.65 & 14.23 & 31 & 20 & 54.91 & 45 & 76.92 & 0.787 \\
\hline 58 & Ain El-Bahariya & 8.1 & 31 & 986 & 636.45 & 260.0 & 57.11 & 28.57 & 106 & 27 & 76.27 & 111.0 & 230.50 & 2.52 \\
\hline 59 & Ain Hadad & 7.02 & 29 & 2425 & 1478.07 & 665.0 & 94.19 & 104.6 & 222 & 60 & 79.32 & 457.0 & 460.99 & 4.26 \\
\hline
\end{tabular}


Table 2. Calculated reservoir temperature according to Giggenbach (1988)'s method (Abd El-Latif, 2007)

\begin{tabular}{|c|c|c|c|c|c|c|c|}
\hline No. & $\begin{array}{c}\text { Total } \\
\text { Depth } \\
\text { (m) }\end{array}$ & $\begin{array}{c}\text { Measured } \\
\mathbf{T}^{0} \mathbf{C}\end{array}$ & $\begin{array}{c}\text { Calculated } \\
\mathbf{T}^{0} \mathbf{C}\end{array}$ & No. & $\begin{array}{c}\text { Total } \\
\text { Depth } \\
\text { (m) }\end{array}$ & $\begin{array}{c}\text { Measured } \\
\mathbf{T}^{\circ} \mathbf{C}\end{array}$ & $\begin{array}{c}\text { Calculated } \\
\mathbf{T}^{0} \mathbf{C}\end{array}$ \\
\hline 1 & 1111 & 47 & 86 & 31 & 660 & 43 & 81 \\
\hline 2 & 500 & 37 & 92 & 32 & 999 & 46 & 78 \\
\hline 3 & 300 & 47 & 90 & 33 & 713 & 47 & 84 \\
\hline 4 & 990 & 47 & 89 & 34 & 1123 & 42 & 71 \\
\hline 5 & 811 & 47 & 79 & 35 & 291 & 30 & 80 \\
\hline 6 & 1200 & 48 & 82 & 36 & 347 & 33 & 88 \\
\hline 7 & 768 & 44 & 90 & 37 & 220 & 31 & 80 \\
\hline 8 & 1082 & 48 & 87 & 38 & 1100 & 22 & 75 \\
\hline 9 & 820 & 43 & 83 & 39 & 210 & 42 & 76 \\
\hline 10 & 600 & 30 & 78 & 40 & 100 & 53 & 74 \\
\hline 11 & 1000 & 38 & 74 & 41 & 371 & 38 & 70 \\
\hline 12 & 1003 & 45 & 78 & 42 & N.D. & 29 & 97 \\
\hline 13 & 1117 & 48 & 80 & 43 & 800 & 44 & 90 \\
\hline 14 & 500 & 32 & 62 & 44 & 794 & 43 & 91 \\
\hline 15 & 799 & 32 & 75 & 45 & 1040 & 47 & 81 \\
\hline 16 & 651 & 51 & 80 & 46 & 1054 & 47 & 83 \\
\hline 17 & 1051 & 46 & 83 & 47 & 498 & 35 & 90 \\
\hline 18 & 840 & 46 & 84 & 48 & 770 & 43 & 87 \\
\hline 19 & 807 & 32 & 84 & 49 & 670 & 32 & 94 \\
\hline 20 & 250 & 36 & 77 & 50 & 500 & 28 & 75 \\
\hline 21 & 807 & 46 & 84 & 51 & N.D. & 52 & 76 \\
\hline 22 & 652 & 37 & 91 & 52 & 780 & 45 & 84 \\
\hline 23 & 335 & 30 & 84 & 53 & 654 & 40 & 84 \\
\hline 24 & 301 & 33 & 72 & 54 & 200 & 52 & 98 \\
\hline 25 & N.D. & 48 & 84 & 55 & N.D. & 55 & 80 \\
\hline 26 & 781 & 42 & 75 & 56 & 324 & 45 & 82 \\
\hline 27 & 746 & 41 & 82 & 57 & N.D. & 40 & 78 \\
\hline 28 & 750 & 40 & 86 & 58 & 816 & 31 & 77 \\
\hline 29 & 305 & 40 & 78 & 59 & 206 & 29 & 81 \\
\hline
\end{tabular}

The groundwater in the study area varies from nonsaline to slightly saline water. An exception is found in one groundwater sample, No.59, which is considered slightly saline (Abd El-Latif, 2007).

In general, the salinity of groundwater increases gradually in the direction of flow (SW-NE) (Fig.2). The increase in the salinity of groundwater in the aforementioned direction may be attributed to the following factors:

1) the changes in lithology and structural pattern of the water-bearing formation,

2)slow groundwater velocity and long distance from the southern to the northern part of the study area, and

3) long residence time.

All ions concentration $\left(\mathrm{Ca}^{++}, \mathrm{Mg}^{++}, \mathrm{Na}^{+}, \mathrm{K}^{+}, \mathrm{HCO}_{3}^{-}\right.$, $\mathrm{SO}_{4}^{--}$and $\mathrm{Cl}^{-}$) show noticeable increase in the same direction of the regional flow of the Nubian Sandstone Aquifer (SW-NE) (Table 1).

\section{Hydrochemical coefficients}

Hydrogeochemical parameters, which are commonly used for identification of groundwater bodies, should be based on and confirmed by hydrogeochemical indicators such as ionic ratios. The cationic and anionic concentrations in these ratios are calculated according to their equivalent concentrations (meq/l). The important ionic ratios which influence the hydrochemical model of the study area are highlighted in the following paragraphs:-

\section{$\mathrm{Na} / \mathrm{Cl}$}

Groundwater flowing through the normal and active hydrological cycle is characterized by $\mathrm{Na} / \mathrm{Cl}$ ratios of $0.86-1.0$ range (0.86 is the ratio of seawater) (Schoeller, 1956, and Hem, 1989). Figure (3) show that $\mathrm{Na} / \mathrm{Cl}$ ratio of groundwater samples from the study area decreases as the salinity increases. The $\mathrm{Na} / \mathrm{Cl}$ ratio in the majority of groundwater samples (59\% of the samples) in the study area are more than those of sea water (0.86) (Fig.3). 
Neal and Kirchner (2000) concluded that the $\mathrm{Na} / \mathrm{Cl}$ ratio in groundwater is higher than the seawater ratio when salinity is low and lower when salinity is high. This behavior is consistent with ion exchange buffering of sodium in the water-bearing formation (Neal and Kirchner, 2000). The $\mathrm{Na} / \mathrm{Cl}$ ratio could reach unity due to mixing of seawater and freshwater, which has a Na/Cl ratio greater than unity (Vengosh and Rosenthal, 1994 and Ghabayen et al., 2006). Mercado (1989) suggested that dissolution of $\mathrm{CaCO}_{3}$ might raise the calcium content in water which is further exchanged with $\mathrm{Na}$ ions, thus causing an increase in $\mathrm{Na} / \mathrm{Cl}$ ratio. In addition, Mercado (1989) suggested that reactions with clays might lead to the exchange of sodium for calcium and/or magnesium ions. By such processes, groundwater may be either enriched or depleted in $\mathrm{Na}$ with the $\mathrm{Na} / \mathrm{Cl}$ ratio changing accordingly (Uliana and Sharp Jr., 2001).

On the other hand, the decrease of Na concentration in some groundwater samples ( $41 \%$ of the samples) may be attributed to cation exchange and mixing with relics of marine water enriched in chloride ions. The equivalent $\mathrm{Na} / \mathrm{Cl}$ ratio for the groundwater samples of the study area indicates that the influence of marine water as a main source of salinization is limited (Abd El-Latif, 2007).

The effect of cation exchange was evaluated by calculating the base exchange index (BEX) (Stuyfzand, 1999) which is defined as follows:

$$
\mathrm{BEX}=(\mathrm{Na}+\mathrm{K}+\mathrm{Mg})-1.076 \mathrm{Cl} \text { in meq/l }
$$

Significantly positive sign of BEX indicates freshening and significantly negative sign indicates salinization and value near zero occurs at equilibrium (Stuyfzand, 1999). The calculated BEX values of the majority of the groundwater samples $(93 \%$ of the samples) of El-BahariyaOasis have significantly positive sign referring to freshening (Table 3).

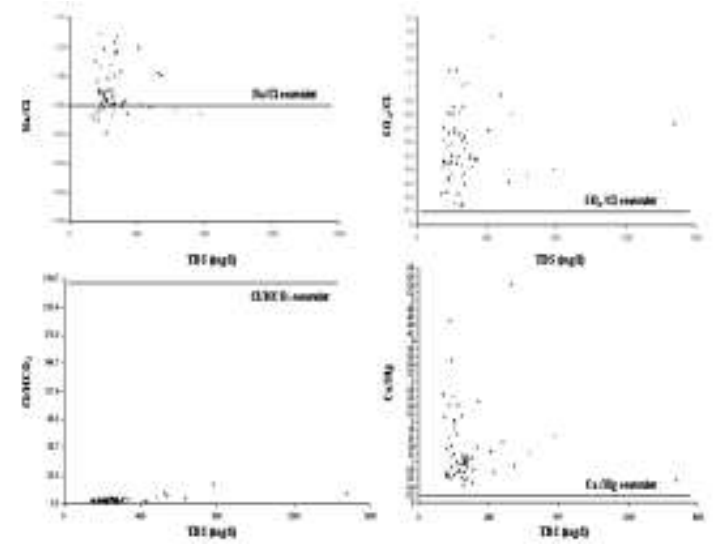

Fig. 3. Relations between salinity and different ionic ratios of groundwater samples of ElBahariya Oasis

\section{$\mathrm{SO}_{4} / \mathrm{Cl}$}

The salinization has been characterized by studying the content of a series of ionic relationships $\left(\mathrm{SO}_{4} / \mathrm{Cl}\right.$, $\mathrm{B} / \mathrm{Li}, \mathrm{Na} / \mathrm{Cl}, \mathrm{Cl} / \mathrm{Br}$ ) (Martos et al., 2002 and Ghabayen et al., 2006 ). Sulfate/chloride and magnesium/calcium ratios showed significant variations in relation to lithological controls and assisted delimitation of continental and marine facies in the aquifer construction and can be taken as a guide for sulfate mineral dissolution. The $\mathrm{SO}_{4} / \mathrm{Cl}$ ratio is not influenced by baseexchange reactions, adsorption onto clay minerals, carbonate-dissolution-precipitation processes and it is considered conservative tracer (Vengosh and Rosenthal, 1994; Vengosh et al., 1994 and Vengosh et al., 1999). Since, dissolution of evaporite leads to an enrichment in sulfate, so the ratio of $\mathrm{SO}_{4} / \mathrm{Cl}$ can be used as a natural tracer (Oliman, 1995; Perry et al., 1995).

About $93 \%$ of the groundwater samples have $\mathrm{SO}_{4} / \mathrm{Cl}$ ratio less than unity but more than that of seawater $(0.1)$ (Fig.3). This indicates the predominance of chloride ions. The dominance of chloride ion is probably due to the leaching of some marine salts from the fluvio-marine sediments which dominate the water-bearing formation or due to mixing with deep-seated salt water that leaks upward along fractures (Abd El-Latif, 2007).

\section{$\mathrm{Ca} / \mathrm{Mg}$}

This ratio usually indicates seawater contamination $(\mathrm{Ca} / \mathrm{Mg}$ is about 0.2$)$ or meteoric water mixing $(\mathrm{Ca} / \mathrm{Mg}$ is about 1.07) in the groundwater bodies. High values of this ratio possibly indicate anhydrite dissolution, meteoric water mixing or $\mathrm{CO}_{2}-\mathrm{CaCO}_{3}$ interaction. Ghabayen et al. (2006) concluded that high values of $\mathrm{Ca} / \mathrm{Mg}$ ratio and high values of $\mathrm{Na} / \mathrm{Cl}$ ratio, relative to seawater, may be caused by dissolution of $\mathrm{CaCO}_{3}$. This raises the $\mathrm{Ca}$ content that is further exchanged with $\mathrm{Na}^{+}$ ions thus causing an increase in the $\mathrm{Na} / \mathrm{Cl}$ ratio (Vengosh and Rosenthal, 1994).

In addition, high $\mathrm{Ca} / \mathrm{Mg}$ ratio may be more pronounced in older waters than in modern waters (Sidenvall, 1981). However, the $\mathrm{Ca} / \mathrm{Mg}$ ratio decreases as the total salinity increases (Fig.3) and is highly influenced by the activity of base exchange processes.

The values of this ratio for groundwater from the Nubian Sandstone Aquifer in the study area (range from 0.14 to 5.4 with an average of 1.4) are higher than that of seawater (Fig.3), thus indicating meteoric water mixing. In general, high TDS values and low $\mathrm{Ca} / \mathrm{Mg}$ ratio characterize the northeastern part of the study area (Abd El-Latif, 2007). 
Table 3. Hydrochemical coefficients of groundwater from the Nubian Sandstone Aquifer in El-Bahariya Oasis (Abd El-Latif, 2007)

\begin{tabular}{|c|c|c|c|c|c|c|c|c|c|c|c|}
\hline No. & BEX & $\mathrm{Na} / \mathrm{Cl}$ & $\mathrm{SO}_{4} / \mathrm{Cl}$ & $\mathrm{Ca} / \mathrm{Mg}$ & $\mathrm{Cl} / \mathrm{Br}$ & No. & BEX & $\mathrm{Na} / \mathrm{Cl}$ & $\mathrm{SO}_{4} / \mathrm{Cl}$ & $\mathrm{Ca} / \mathrm{Mg}$ & $\mathrm{Cl} / \mathrm{Br}$ \\
\hline 1 & 0.03 & 0.84 & 0.36 & 2.00 & 110.59 & 32 & 0.73 & 0.87 & 0.42 & 0.79 & 124.30 \\
\hline 2 & 1.18 & 1.24 & 0.63 & 1.12 & 107.24 & 33 & 0.87 & 1.38 & 0.66 & 1.11 & 33.83 \\
\hline 3 & 0.28 & 0.89 & 0.22 & 0.93 & 94.07 & 34 & 1.16 & 1.14 & 1.11 & 0.59 & 457.87 \\
\hline 4 & 0.95 & 1.15 & 0.65 & 0.94 & 94.22 & 35 & 1.06 & 0.84 & 0.94 & 1.49 & 126.94 \\
\hline 5 & 0.76 & 0.93 & 0.61 & 0.73 & 110.58 & 36 & -0.06 & 0.74 & 0.80 & 3.50 & 49.56 \\
\hline 6 & 0.47 & 0.94 & 0.33 & 0.86 & 137.06 & 37 & 0.20 & 0.80 & 0.44 & 1.33 & 423.82 \\
\hline 7 & 0.07 & 0.83 & 0.14 & 1.04 & 86.78 & 38 & 0.83 & 1.18 & 0.70 & 0.68 & $\ldots$ \\
\hline 8 & 0.29 & 0.95 & 0.34 & 1.40 & 113.46 & 39 & 0.75 & 1.02 & 0.61 & 0.75 & 460.22 \\
\hline 9 & -0.11 & 0.78 & 0.22 & 2.66 & 306.40 & 40 & 0.80 & 0.96 & 0.81 & 0.69 & 262.24 \\
\hline 10 & 1.72 & 1.28 & 0.68 & 1.27 & 92.65 & 41 & 1.51 & 0.78 & 1.01 & 0.41 & 272.29 \\
\hline 11 & 1.06 & 1.10 & 0.50 & 1.10 & 89.78 & 42 & -0.05 & 0.79 & 0.40 & 1.63 & 106.16 \\
\hline 12 & 0.12 & 0.87 & 0.45 & 2.61 & 120.85 & 43 & 1.16 & 0.96 & 1.12 & 0.77 & $\ldots$ \\
\hline 13 & 0.50 & 0.92 & 0.58 & 1.20 & 147.07 & 44 & 0.03 & 0.85 & 0.13 & 1.15 & 114.20 \\
\hline 14 & 2.25 & 0.85 & 1.36 & 0.74 & 109.38 & 45 & 0.68 & 1.27 & 0.80 & 2.00 & 207.62 \\
\hline 15 & 0.22 & 0.65 & 0.69 & 1.67 & 243.15 & 46 & 0.67 & 0.95 & 0.50 & 0.67 & 139.05 \\
\hline 16 & 0.52 & 0.97 & 0.81 & 2.14 & 94.97 & 47 & 1.56 & 1.36 & 1.02 & 0.82 & 158.11 \\
\hline 17 & 0.45 & 1.05 & 0.44 & 2.40 & 72.99 & 48 & -0.12 & 0.79 & 0.47 & 2.50 & 117.03 \\
\hline 18 & 0.49 & 0.88 & 0.47 & 1.36 & 78.61 & 49 & 0.45 & 1.09 & 0.31 & 5.40 & 136.05 \\
\hline 19 & 0.03 & 0.76 & 0.41 & 2.11 & 299.70 & 50 & 2.15 & 1.07 & 0.80 & 0.91 & 115.86 \\
\hline 20 & 0.43 & 0.83 & 0.85 & 1.83 & 227.36 & 51 & 0.65 & 0.88 & 0.66 & 1.00 & 160.26 \\
\hline 21 & 0.39 & 0.86 & 0.29 & 1.00 & 97.68 & 52 & 1.07 & 1.06 & 0.55 & 0.91 & 113.12 \\
\hline 22 & 1.23 & 1.25 & 0.59 & 1.06 & 133.60 & 53 & 1.20 & 1.08 & 0.37 & 0.58 & 133.08 \\
\hline 23 & 0.14 & 0.80 & 0.56 & 2.40 & 184.62 & 54 & 0.13 & 1.04 & 0.32 & 4.49 & 150.83 \\
\hline 24 & 0.48 & 0.74 & 0.46 & 0.65 & 227.36 & 55 & 0.33 & 0.97 & 0.44 & 1.60 & 122.36 \\
\hline 25 & 0.32 & 0.90 & 0.15 & 0.72 & 94.15 & 56 & 0.91 & 1.05 & 0.49 & 0.76 & 71.67 \\
\hline 26 & 1.14 & 0.84 & 0.48 & 0.48 & 78.29 & 57 & 0.70 & 0.86 & 0.43 & 1.01 & 97.74 \\
\hline 27 & 1.63 & 1.32 & 0.85 & 0.53 & 65.68 & 58 & 0.66 & 0.82 & 0.35 & 1.21 & 91.47 \\
\hline 28 & 0.17 & 0.85 & 0.16 & 1.07 & 89.97 & 59 & 5.80 & 0.86 & 0.73 & 0.55 & 108.21 \\
\hline 29 & 0.34 & 0.83 & 0.23 & 0.62 & 136.61 & & & & & & \\
\hline 30 & 0.50 & 0.85 & 0.22 & 0.60 & 102.45 & & & & & & \\
\hline 31 & 0.66 & 0.91 & 0.35 & 0.93 & 110.58 & & & & & & \\
\hline
\end{tabular}

\section{$\mathrm{Cl} / \mathrm{Br}$}

The cationic and anionic concentrations in this ratio is calculated according to its milligram concentrations (mg/l). The $\mathrm{Cl} / \mathrm{Br}$ ratio was previously identified to differentiate between sources of salinization (Starinsky et al., 1983; Richter et al., 1990; Vengosh and Rosenthal, 1994; Davis et al., 1998; Martos et al., 2002, Edmunds, 1996; Edmunds et al., 2003 and Ghabayen et al., 2006). The $\mathrm{Cl} / \mathrm{Br}$ ratio is not influenced by baseexchange reactions, adsorption onto clay minerals, carbonate-dissolution-precipitation processes and it is considered a conservative tracer (Carpenter, 1978; Stoessell and Carpenter, 1986; Whittemore, 1988,
Vengosh and Rosenthal, 1994; Vengosh et al., 1994 and Vengosh et al., 1999). The ratio of $\mathrm{Cl} / \mathrm{Br}$ can be classified into three types: rock salt type $(\mathrm{Cl} / \mathrm{Br}$ ratio of 2500 or more), secondary salt type (288-2500) and rain water type (288 or less) (Imaizumi et al., 2001). According to this classification, the majority of the groundwater samples $(91 \%)$ from the study area have $\mathrm{Cl} / \mathrm{Br}$ values less than 288 (Fig.4), which indicates that the groundwater is of rain water type (meteoric origin). On the other hand, some groundwater samples $(9 \%)$ have $\mathrm{Cl} / \mathrm{Br}$ values (>288 to 460 ), indicating the involvement of traces of marine water. 


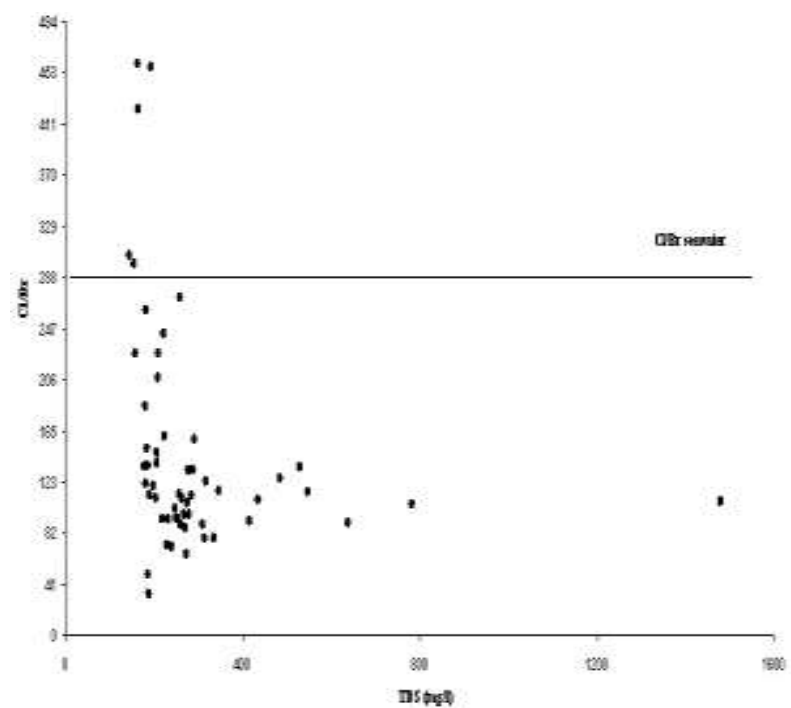

Fig. 4. between salinity and $\mathrm{Cl} / \mathrm{Br}$ ratio of groundwater samples of El- Bahariya Oasis (after Abd El-Latif, 2007)

\section{Hydrochemical facies and genetic classification of groundwater}

The trilinear plotting classification method Piper's (1944) diagram

Piper's diagram for groundwater samples of the study area (Fig.5) illustrates that most of groundwater samples $(61 \%)$ are located within sub-area 9, while other groundwater samples $20 \%$ and $19 \%$ lie in sub-area 7 and sub-area 6, respectively. The samples located within sub-area 9 (i.e. No one cation-anion pair > 50\%) are shown to be more influenced by meteoric replenishment in the past time, while those located within sub-area 7 and sub-area 6 are shown to be more affected by marine water and non carbonate hardness "secondary salinity" $>50 \%$, respectively. Finally, this diagram suggests that the groundwater from the Nubian Sandstone Aquifer in El-Bahariya Oasis have mixed types of mineralization, i.e., pure meteoric water that vertically infiltrated and settled in the aquifer materials during the past Pluvial times and those affected through groundwater flow by relics of marine water (Abd ElLatif, 2007).

Sulin's (1948) diagram.

Sulin's (1948) diagram is usually used to reveal the water genesis and the type of water from the hydrochemical composition. Plotting of the groundwater samples from the Nubian Sandstone Aquifer on Sulin's diagram (Fig.6) shows that more than $50 \%$ of the collected samples are of marine origin ( $\mathrm{Cl}-\mathrm{Mg}$ type), where the rest are of $\mathrm{SO}_{4}$-Na type (i.e. meteoric origin).

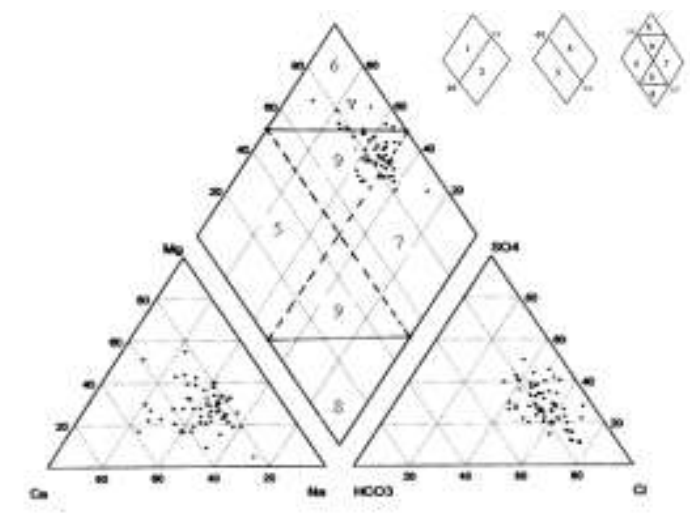

Fig.5. Piper's diagram for groundwater samples of the Nubian Sandstone Aquifer in ElBahariya Oasis

However, it is noteworthy to mention that the genetic classification of groundwater according to the $\mathrm{Cl} / \mathrm{Br}$ ratio which indicates that the majority of the groundwater samples (91\%) is of rain water type (meteoric origin) is more reliable than that of Sulin's diagram classification (i.e. $>50 \%$ of the collected

samples are of marine origin, $\mathrm{Cl}-\mathrm{Mg}$ type). This may be attributed to the conservative nature of $\mathrm{Cl}$ and $\mathrm{Br}$ in the groundwater system (Abd El-Latif, 2007), whereas Sulin's classification involves non-conservative ions like $\mathrm{Na}, \mathrm{Ca}$ and $\mathrm{Mg}$ which are strongly affected by hydrogeochemical processes of cation exchange and dissolution-precipitation reactions.

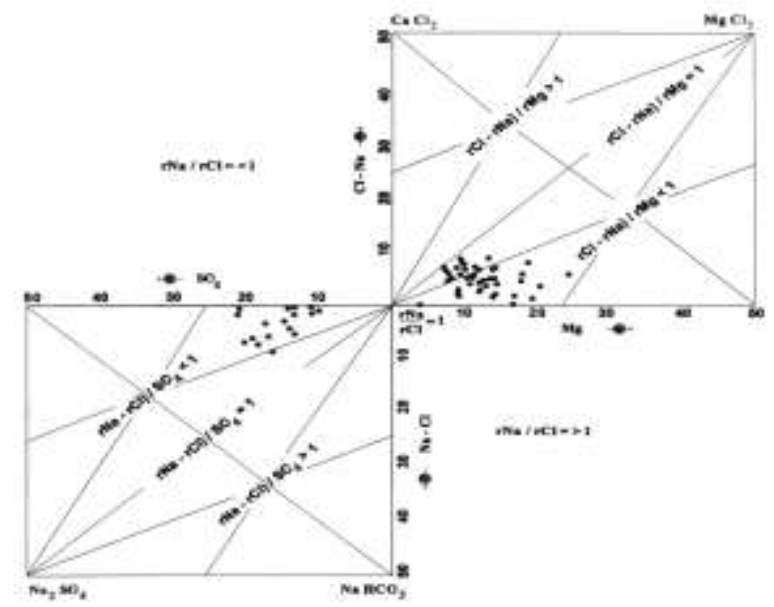

Fig.6. Sulin's diagram for ground-water samples of El-Bahariya Oasis

\section{Durov's (1948) diagram}

Evidence of cation exchange and reverse cation exchange in the Nubian Sandstone Aquifer system can be revealed from the Durov's diagram (expanded) (Fig.7). It shows evolutionary trends and hydrochemical processes occurring in the groundwater system. The 
significance of each of the nine fields on the expanded Durov diagram is as follows (Lloyd, 1985):

\section{Durov's field}

Field 1

Fields 2\&3

Fields $4 \& 5$

Field 6

Fields $7 \& 8$

Field 9

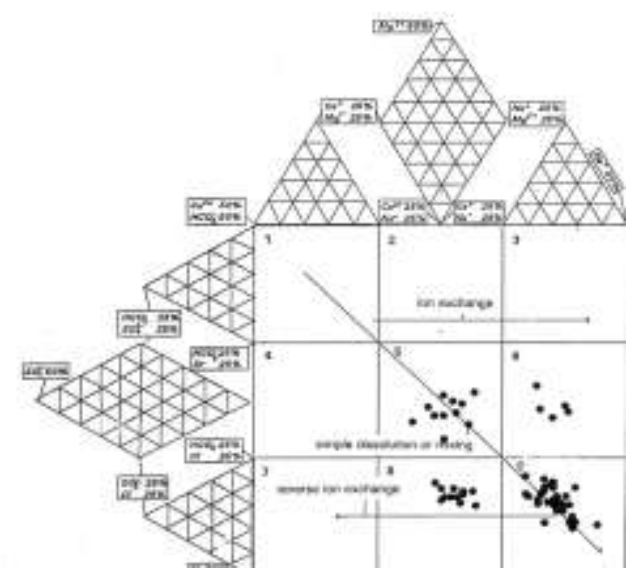

Fig.7. Expanded Durov's diagram for different water types of the collected groundwaters of EIBahariya Oasis

The arrows in Fig.7 indicate possible process paths, such as ion exchange or dissolution. From the Durov's diagram, it is obvious that most of the groundwater samples representing the Nubian Sandstone Aquifer in El-Bahariya Oasis are plotted in field 9 (Cl-Na type) which indicates end-point water (i.e. more developed stage of mineralization) (Abd El-Latif, 2007). Some of the plotted groundwater samples $(20 \%, 19 \%$ and $8 \%)$ are located in fields $(8,5$ and 6$)$ of $\mathrm{Cl}-\mathrm{Mg}, \mathrm{SO}_{4}-\mathrm{Mg}$ and $\mathrm{SO}_{4}-\mathrm{Na}$ type, respectively. These waters represent less advanced stage of mineralization. It is also clear that the groundwaters of the study area have a mixed origin (pure meteoric water affected to less extent by traces of marine water). Therefore, the groundwater acquires its quality from mixing, cation exchange and dissolution of salts by interaction with clays, shales, carbonates and sulfates in the aquifer matrix.

\section{Quality Assessment}

The main aquifer is the highly productive artesian Nubian Sandstone Aquifer. This groundwater is being, and will be, used as an essential source of water for agricultural expansion, as well as for industrial development and domestic usages, particularly in the newly established communities and industrial zones. In fact, greater residential development and population density brings greater potential for human effects on water quality (Eckardt and Stackelberg, 1995; and Thomas, 2000). Therefore, water resource management and water availability are among the most important political, social and economical issues of the $21^{\text {st }}$ century (Harsh et al. 1989 and Krug, 1989) as water quality assessment is becoming a major concern in ElBahariya Oasis.

\section{1) Assessment for drinking and domestic purposes}

Water-quality standards published by various agencies are used for drinking and domestic uses owing to evaluate the suitability of water for public supply. Accordingly, the majority of groundwater samples of the Nubian Sandstone Aquifer of El-Bahariya Oasis are suitable for drinking and domestic uses under normal conditions except for iron and manganese.

The concentrations of the trace elements are far below the drinking water permissible limits, except for aluminum where $25 \%$ of groundwater samples have higher concentrations. Therefore, most of groundwater samples are suitable for human drinking (Abd El-Latif, 2007).

\section{2)Assessment for irrigation and salinity management}

One of the most widely advocated water management objectives in Egypt is the improvement of water-use efficiency in agriculture. Irrigation is the most effective mean of increasing food production in Egypt. Therefore, the main purpose of irrigation is to assure a given quantity and quality of water being made available at a given place and at a given time (Hall, 1976).

Generally, irrigation water requirements depend on three factors, climate, plant type, and drainability of soil. Thus, rigorous universal standards for these water requirements can not be formulated, and what may be poor quality under certain conditions could be quite acceptable under other conditions.

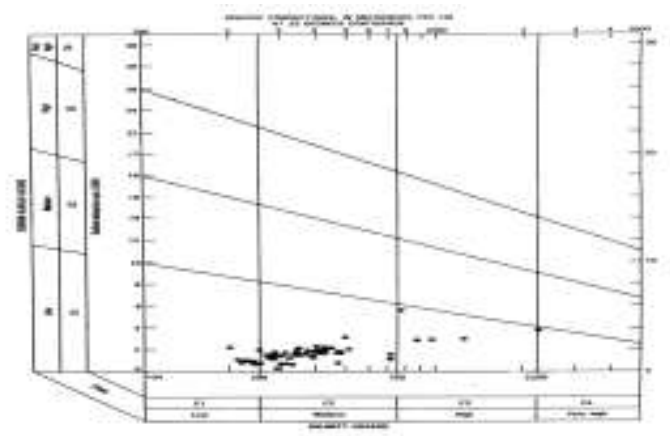

Fig.8. Classification of groundwater samples from El-Bahariya Oasis according to US Salinity Laboratory Staff, 1954 


\section{i) The U.S. Salinity Laboratory (1954) classification}

The U.S. Salinity Laboratory classification is widely used normogram for evaluating waters for irrigation purposes (Table 4). Accordingly, the waters are divided into four classes on the basis of salinity $\left(\mathrm{C}_{1}, \mathrm{C}_{2}, \mathrm{C}_{3}, \&\right.$ $\mathrm{C}_{4}$ ) and four classes on the basis of sodium adsorption ratio $\left(S_{1}, S_{2}, S_{3}, \& S_{4}\right)$ giving a total of sixteen possible quality classes $\left(C_{1}-S_{1}, C_{1}-S_{2} \ldots\right.$. etc. $)$ (Table 4$)$.

The sodium adsorption ratio has been introduced by Richards (1954) as follows:

$$
\mathrm{SAR}=\frac{\mathrm{Na}}{\sqrt{\frac{(\mathrm{Ca}+\mathrm{Mg})}{2}}} \quad \text { (in meq/1) }
$$

The concentration of sodium, calcium and magnesium are expressed in meq/l. High SAR (sodium hazard) leads to the breakdown in the physical structure of the soil. Such soils can crust badly and swell or disperse thus reducing the soil permeability (Buckman and Brady (1967), Chen and Banin (1975), Ayers and Westcot (1976), Frenkel et al. (1978), Hardy et al. (1983), Miller and Donahue (1995), Hanson et al. (1999), Falstad (2000), Van de Graaff and Paterson (2001), Bauder (2001), Bauder and Brock (2001), Ali et al. (2002) and Barbiéro et al., 2004). Sodium is adsorbed, replacing calcium and magnesium (cation exchange reaction) and becomes attached to soil particles which becomes hard and compact when dry. The interaction of clay surface with ions has great influence on physicochemical behavior of soils. The types and concentration of ions in soil solution govern the dominance of attracting and repelling forces and the resulting flocculation or deflocculation of clays. Divalent exchangeable cations result in flocculated clay systems while monovalent exchangeable cations produce dispersed or deflocculated systems (Aydin et al., 2000 and Aydin et al., 2004). In other words, by replacing the $\mathrm{Na}$ adsorbed on the clay with $\mathrm{Ca}$, the thickness of the electrical double layer is reduced and thus soil colloids flocculate. From the plotted samples on the normogram (Fig.8), the major classes of the groundwater of El-Bahariya Oasis are given in Table (5). Concerning salinity and sodium hazards, groundwater in El-Bahariya Oasis is considered as good class $\left(76 \% \mathrm{C}_{2}-\mathrm{S}_{1}, 15 \% \mathrm{C}_{1}-\mathrm{S}_{1}, 7 \% \mathrm{C}_{3}-\mathrm{S}_{1}\right.$ and $\left.2 \% \mathrm{C}_{4}-\mathrm{S}_{1}\right)$.

Thus, groundwater samples from the Nubian Sandstone Aquifer are suitable for irrigation under normal condition (Abd El-Latif, 2007)

\section{ii) Wilcox's (1948) classification}

It suggests the definition of sodium percentage relative to common cations percentage as shown in the following equation:

$$
\mathrm{Na} \%=\frac{\mathrm{Na} \times 100}{\mathrm{Ca}+\mathrm{Mg}+\mathrm{Na}} \text { (in meq/l) }
$$

Wilcox classification is essentially based on the relation between $\mathrm{Na}$ and salinity, which defines the suitability of water for irrigation and the potential for plant toxicity. In the study area, $92 \%$ of the groundwater samples (Table 6 and Fig.9) are plotted in the field of excellent to good water class (i.e. suitable for irrigation) while $5 \%, 2 \%$ and $1 \%$ of water samples varying from good to permissible, permissible to doubtful, and doubtful to unsuitable class, respectively.

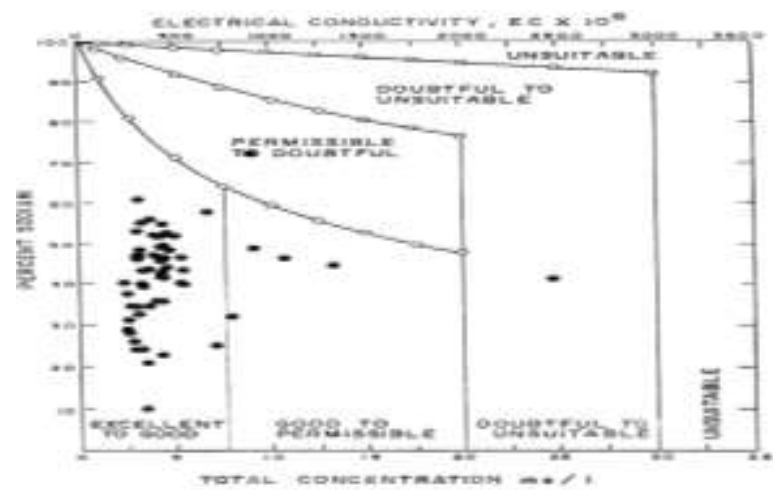

Fig.9. Classification of groundwater samples from El-Bahariya Oasis based on Wilcox's (1948)

Table 4. Water quality-class according to .S. Salinity Lab. (1954)

\begin{tabular}{clclcccc}
\hline $\begin{array}{c}\text { EC } \\
\text { class }\end{array}$ & Water Quality & $\begin{array}{c}\text { Range EC } \\
\text { (us/cm) }\end{array}$ & \multicolumn{1}{c}{ Us age } & $\begin{array}{c}\text { SAR } \\
\text { class }\end{array}$ & Water Quality & Range & Us age \\
\hline $\mathrm{C}_{1}$ & Low salinity & $100-250$ & $\begin{array}{l}\text { Can be used for } \\
\text { irrigation with most } \\
\text { crops on most soils }\end{array}$ & $\mathrm{S}_{1}$ & Low sodium & 0.10 & Can be used for all soils \\
\hline $\mathrm{C}_{2}$ & Medium & $250-750$ & $\begin{array}{l}\text { Can be used if moderate } \\
\text { leaching occurs }\end{array}$ & $\mathrm{S}_{2}$ & $\begin{array}{c}\text { Medium } \\
\text { sodium }\end{array}$ & $10-18$ & $\begin{array}{c}\text { Preferably used with } \\
\text { good permrability }\end{array}$ \\
\hline $\mathrm{C}_{3}$ & Hilinity & $750-2250$ & $\begin{array}{l}\text { Cannot be used with } \\
\text { restricted drainage }\end{array}$ & $\mathrm{S}_{3}$ & High sodium & $18-26$ & $\begin{array}{l}\text { Can produce a harmful } \\
\text { effects }\end{array}$ \\
\hline $\mathrm{C}_{4}$ & $\begin{array}{l}\text { Very high } \\
\text { salinity }\end{array}$ & $>2250$ & $\begin{array}{l}\text { Not suitable for } \\
\text { irrigation under ordinary } \\
\text { conditions }\end{array}$ & $\mathrm{S}_{4}$ & Very high & 26-100 & $\begin{array}{l}\text { Unsuitable for } \\
\text { rigation expect at low } \\
\text { \& medium salinity }\end{array}$ \\
\hline
\end{tabular}

Note: 1- The $\mathrm{C}_{2} \mathrm{~S}_{2}$ and $\mathrm{C}_{3} \mathrm{~S}_{3}$ water can be improved by adding gypsum to the soil peciodically.

2- the $\mathrm{C}_{4} \mathrm{~S}_{4}$ may be improved by addition of gypsum to the water 


\section{iii) Eaton's (1950) classification}

Some water, when used for the irrigation of crops, has a tendency to produce alkalinity/sodicity hazards, depending upon the absolute and relative concentrations of specific cations and anions. The alkalinity is generally measured in terms of the sodium adsorption ratio (SAR), residual sodium carbonate (RSC) and adjusted SAR (Tyagi, 2003). In fact, the effect of bicarbonate ions on the increase of soil alkalinity and on lime accumulation is very important. Concerning the bicarbonate content of the water, Eaton (1950) was the first to introduce the residual sodium carbonate (RSC) value expressed by the equation:

$\mathrm{RSC}=\left(\mathrm{CO}_{3}+\mathrm{HCO}_{3}\right)-(\mathrm{Ca}+\mathrm{Mg})($ in meq/l)

According to the residual sodium carbonate, the irrigation water can be divided into three classes as follows:

i) Safe, if $\mathrm{RSC}<1.25 \mathrm{meq} / \mathrm{l}$ (i.e. negative values indicate no problem);

ii) Marginal, if RSC ranges from 1.25 to $2.5 \mathrm{meq} / \mathrm{l}$, and iii)Unsuitable, if RSC > $2.5 \mathrm{meq} / \mathrm{l}$

Since, high concentration of bicarbonate is associated with an increase in the $\mathrm{pH}$ values which causes the dissolution of the organic matter (FAO, 1985). Moreover, high concentration of bicarbonate in irrigation water leads to its toxicity and effects the mineral nutrition of many plants. Generally, carbonate and bicarbonate can also affect infiltration (FAO, 1985).

Table (7) shows that the RSC values of the groundwater samples of the study area are less than 1.25 , indicating that the groundwater of the Nubian Sandstone Aquifer can be safely used for irrigation (Abd El-Latif, 2007).

\section{iv) Boron content}

Boron is an essential micro-nutrient to proper plant nutrition and required only in very small amounts, however, greater concentration of boron in soil and in irrigation water are harmful (i.e. toxic to some plants) (Hem, 1989). Sprague (1972) mentioned that boron in natural waters exists primarily as undissociated boric acid with some borate ions. Leeden and Todd (1990) introduced limits of boron in irrigation water depending upon the boron requirements for different types of crops as shown in Table (8):

In El-Bahariya Oasis, the groundwater samples of the Nubian Sandstone Aquifer have boron contents range from 0.010 to $0.076 \mathrm{mg} / \mathrm{l}$ with an average of 0.043 $\mathrm{mg} / \mathrm{l}$. Based on this classification, all the groundwater samples in the study area can be grouped into the excellent classes for different kinds of crops including sensitive, semitolerant and tolerant (Abd El-Latif, 2007)

Table 7. Calculated values of RSC for the groundwater of El-BahariyaOasis

\begin{tabular}{|c|c|c|c|c|c|}
\hline $\begin{array}{l}\text { Well } \\
\text { No. }\end{array}$ & RSC & $\begin{array}{l}\text { Asses- } \\
\text { sment }\end{array}$ & $\begin{array}{c}\text { Well } \\
\text { No. }\end{array}$ & RSC & $\begin{array}{l}\text { Asses- } \\
\text { sment }\end{array}$ \\
\hline 1 & -1.01 & Safe & 31 & -1.18 & Safe \\
\hline 2 & -0.84 & Safe & 32 & -1.89 & Safe \\
\hline 3 & -0.97 & Safe & 33 & -0.45 & Safe \\
\hline 4 & -1.09 & Safe & 34 & -1.18 & Safe \\
\hline 5 & -1.50 & Safe & 35 & -4.28 & Safe \\
\hline 6 & -0.79 & Safe & 36 & -1.48 & Safe \\
\hline 7 & -1.16 & Safe & 37 & -1.00 & Safe \\
\hline 8 & -0.84 & Safe & 38 & -0.58 & Safe \\
\hline 9 & -0.61 & Safe & 39 & -0.68 & Safe \\
\hline 10 & -1.47 & Safe & 40 & -1.21 & Safe \\
\hline 11 & -1.15 & Safe & 41 & -2.34 & Safe \\
\hline 12 & -1.09 & Safe & 42 & -5.88 & Safe \\
\hline 13 & -1.17 & Safe & 43 & -1.45 & Safe \\
\hline 14 & -4.02 & Safe & 44 & -1.01 & Safe \\
\hline 15 & -1.74 & Safe & 45 & -0.65 & Safe \\
\hline 16 & -1.63 & Safe & 46 & -1.07 & Safe \\
\hline 17 & -0.78 & Safe & 47 & -1.14 & Safe \\
\hline 18 & -1.88 & Safe & 48 & -2.08 & Safe \\
\hline 19 & -0.95 & Safe & 49 & -1.67 & Safe \\
\hline 20 & -1.44 & Safe & 50 & -3.63 & Safe \\
\hline 21 & -1.43 & Safe & 51 & -1.48 & Safe \\
\hline 22 & -0.68 & Safe & 52 & -1.24 & Safe \\
\hline 23 & -1.10 & Safe & 53 & -0.80 & Safe \\
\hline 24 & -1.03 & Safe & 54 & -0.59 & Safe \\
\hline 25 & -0.78 & Safe & 55 & -0.87 & Safe \\
\hline 26 & -2.07 & Safe & 56 & -0.99 & Safe \\
\hline 27 & -1.12 & Safe & 57 & -1.45 & Safe \\
\hline 28 & -1.05 & Safe & 58 & -3.95 & Safe \\
\hline 29 & -0.87 & Safe & 59 & -12.00 & Safe \\
\hline 30 & -1.19 & Safe & & & \\
\hline
\end{tabular}

Table 8. Limits of boron in irrigation wateraccording to Leeden and Todd (1990)

\begin{tabular}{lccc}
\hline Class of & \multicolumn{2}{c}{ Permissible Limits (Boron in mg/l) } \\
\cline { 2 - 4 } water & \multicolumn{2}{c}{ Crop group } \\
\cline { 2 - 4 } Excellent & $<0.33$ & Semitolerant & Tolerant \\
\hline Good & 0.33 to 0.67 & 0.67 to 1.33 & 1.0 to 2.0 \\
\hline Permissible & 0.67 to 1.0 & 1.33 to 2.0 & 2.0 to 3.0 \\
\hline Doubtful & 1.0 to 1.25 & 2.0 to 2.5 & 3.0 to 3.75 \\
\hline Unsuitable & $>1.25$ & $>2.5$ & $>3.75$ \\
\hline
\end{tabular}

\section{v) Minor and trace elements}

The terms "minor" and "trace" are commonly used for substances that always or nearly always occur in concentration less than $1.0 \mathrm{mg} / \mathrm{l}$ (Hem, 1989).

In general, the most important minor elements are boron, iron and nitrate. Recommended maximum limits 
for constituents in irrigation water presented by the National Academy of Sciences and National Academy of Engineering (1972) and Rowe and Abdel-Magid (1995) are given in Table (9).

Assessment of the groundwater quality of the study area for safe irrigation is carried out through the determination of two minor elements ( $\mathrm{B}$ and $\mathrm{Fe}$ ) and nine trace elements $(\mathrm{Al}, \mathrm{Cd}, \mathrm{Cr}, \mathrm{Co}, \mathrm{Cu}, \mathrm{Pb}, \mathrm{Mn}, \mathrm{Ni}$, and $\mathrm{Zn}$ ) in 58 groundwater samples that were collected from El-Bahariya Oasis in December 2002 (Table 11).

Table 9. Recommended maximum limits (mg/l) for minor and trace elements in irrigation water according to NAS-NAE (1972)and Rowe and Abdel-Magid (1995)

\begin{tabular}{|c|c|c|c|c|c|}
\hline Const. & $\begin{array}{l}\text { Long-term } \\
\text { use }^{(a)} \\
\text { (mg/l) }\end{array}$ & $\begin{array}{l}\text { Short- } \\
\text { term } \\
\text { use }^{(b)} \\
\text { mg/l) }^{\text {b }}\end{array}$ & Const. & $\begin{array}{l}\text { Long- } \\
\text { term } \\
\text { use }^{(a)} \\
\text { (mg/l) }\end{array}$ & $\begin{array}{l}\text { Short- } \\
\text { term } \\
\text { use }{ }^{(b)} \\
\text { (mg/l) }\end{array}$ \\
\hline $\begin{array}{l}\text { Alumi } \\
\text { num }\end{array}$ & 5.0 & 20.0 & Iron & 5.0 & 20.0 \\
\hline Arseni & 0.1 & 2.0 & Lead & 5.0 & 10.0 \\
\hline Berylli & 0.1 & 0.5 & Lithium & 2.5 & 2.5 \\
\hline Boron & 0.75 & 2.0 & Manganese & 0.2 & 10.0 \\
\hline Cadmi & 0.01 & 0.05 & Molybdenu & 0.01 & 0.05 \\
\hline Chrom & 0.1 & 1.0 & Nickel & 0.2 & 2.0 \\
\hline Cobalt & 0.05 & 5.0 & Selenium & 0.02 & 0.02 \\
\hline Coppe & 0.2 & 5.0 & Vanadium & 0.1 & 1.0 \\
\hline Fluori & 1.0 & 15.0 & Zinc & 2.0 & 10.0 \\
\hline
\end{tabular}

${ }^{\mathrm{a}}$ For water used continuously on all soils. ${ }^{\mathrm{b}}$ For water used for a period of up to 20 years on fine-textured neutral or alkaline soils.

The permissible iron content in irrigation water is 5 $\mathrm{mg} / \mathrm{l}$, whereas the iron content, in the investigated groundwater samples (Tables 10 and 11), ranges between 0.01 to $10.29 \mathrm{mg} / \mathrm{l}$ with a mean value of 1.87 $\mathrm{mg} / \mathrm{l}$. Therefore, the majority of the groundwater samples (95\%) have iron content below the permissible level for irrigation while $5 \%$ exceed the recommended value.

Several classifications and standard limits are used to assess the suitability of the groundwater of the study area for irrigation. A complete water quality management will define the suitability of water for irrigation, which associated with soil nature and crop type, and the potential for plant toxicity. For irrigation, water quality is related to its effect on soils and crops, and on the management that may be necessary to control or compensate for the water quality related problems (Ayers and Westcot, 1976). Depending upon the above mentioned classifications, the majority of groundwater sample of El-Bahariya Oasis can be used for irrigation under ordinary circumstances with little exception that leads to the optimum level of the expected productivity(Abd El-Latif, 2007).
Table 10. Results of chemical analysis of minor elements $(\mathrm{mg} / \mathrm{l})$ of the groundwater samples of El-Bahariya Oasis

\begin{tabular}{|c|c|c|c|c|c|}
\hline $\begin{array}{l}\text { Well } \\
\text { No. }\end{array}$ & B & $\mathrm{Fe}$ & $\begin{array}{l}\text { Well } \\
\text { No. }\end{array}$ & B & $\mathrm{Fe}$ \\
\hline 1 & 0.0200 & 0.0110 & 31 & 0.0521 & 1.5100 \\
\hline 2 & 0.0402 & 0.0150 & 32 & 0.0425 & 2.0500 \\
\hline 3 & 0.0311 & 0.5839 & 33 & 0.0340 & 1.5420 \\
\hline 4 & 0.0236 & 0.0101 & 34 & 0.0325 & 0.2212 \\
\hline 5 & 0.0258 & 0.2816 & 35 & 0.0573 & 5.9370 \\
\hline 6 & 0.0228 & 1.3080 & 36 & 0.0337 & 3.3180 \\
\hline 7 & 0.0482 & 1.4140 & 37 & 0.0282 & 0.8687 \\
\hline 8 & 0.0209 & 2.2290 & 38 & 0.0301 & 0.4912 \\
\hline 9 & 0.0195 & 2.5020 & 39 & 0.0341 & 1.6060 \\
\hline 10 & 0.0710 & 1.5150 & 40 & 0.0439 & 2.2720 \\
\hline 11 & 0.0670 & 0.6617 & 41 & 0.0274 & 0.5868 \\
\hline 12 & 0.0315 & 3.7760 & 42 & 0.0377 & 4.9820 \\
\hline 13 & 0.0146 & 0.3367 & 43 & 0.0284 & 0.4536 \\
\hline 14 & 0.0446 & 10.2900 & 44 & 0.0548 & 2.1630 \\
\hline 15 & 0.0109 & 3.1460 & 45 & 0.0386 & 3.1590 \\
\hline 16 & 0.0208 & 2.8080 & 46 & 0.0362 & 1.3950 \\
\hline 17 & 0.0213 & 2.5090 & 47 & 0.0585 & 0.0430 \\
\hline 18 & 0.0341 & 2.7510 & 48 & 0.0544 & 0.1751 \\
\hline 19 & 0.0099 & 2.7720 & 49 & 0.0513 & 1.4520 \\
\hline 20 & 0.0140 & 4.2790 & 50 & 0.0450 & 0.5343 \\
\hline 21 & 0.0717 & 2.3490 & 51 & 0.0328 & 0.7139 \\
\hline 22 & 0.0755 & 0.4819 & 52 & 0.0449 & 0.0152 \\
\hline 23 & 0.0431 & 3.1420 & 53 & 0.0455 & 0.2030 \\
\hline 24 & 0.0432 & 4.5110 & 54 & 0.0383 & 0.1823 \\
\hline 25 & 0.0635 & 7.0390 & 55 & 0.0331 & 2.2380 \\
\hline 26 & 0.0600 & 2.3190 & 56 & 0.0361 & 0.1526 \\
\hline 27 & 0.0587 & 1.7820 & 57 & 0.036 & 0.153 \\
\hline 28 & 0.0522 & 0.4292 & 58 & 0.0670 & 0.2161 \\
\hline 29 & 0.0481 & 4.5680 & 59 & $\ldots$ & $\ldots$ \\
\hline 30 & 0.0508 & 1.8290 & & & \\
\hline
\end{tabular}

Table 11. The range and mean values of trace elements $(\mathrm{mg} / \mathrm{l})$ of the groundwater samples of Bahariya Oasis

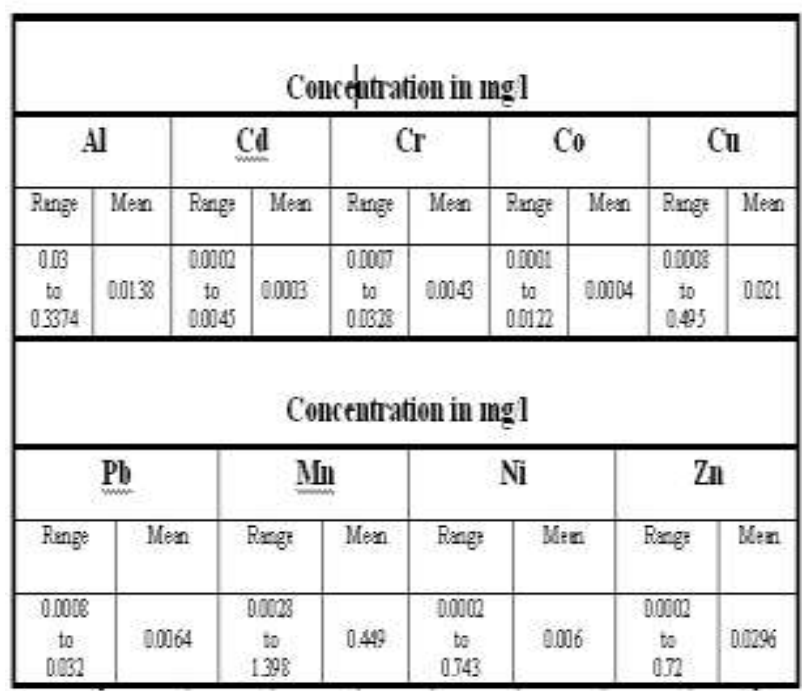




\section{3)Assessment of groundwater for industrial purposes}

In the study area, plentiful groundwater supply from the Nubian Aquifer is considered to have played an important role in the province's socio-economic development. From the economic viewpoint, it may be necessary to site water consuming industries in areas where there is an abundant natural supply of suitable water (Matthess, 1982). Water required for industrial purposes depends on the requirements of particular industry; some may need water to be more pure than domestic, whereas others may require some specific minerals to be absent. For instance, the water quality for food and medicinal drug industries must be at least as that of drinking water. For textile industries, water should be low in iron, manganese, other heavy metals, total salts and hardness. There are many quality parameters that must be considered when using water resources for industry:

\section{1) Total Dissolved Solids (TDS):}

High TDS levels (> 500) result in excessive scaling in water pipes, water heaters, boilers, and household appliance such as kettles and steam irons (Tihansky, 1974 and McQuillan and Spent, 1976). Such scaling can shorten the service life of these appliances.

\section{2) Total Hardness:}

Hardness of water is defined as its content of metallic ions which react with soaps to produce scuds or scummy residues; and which react with negative ions when water is evaporated in boilers to produce solid boiler scale and is expressed, as follows:

Total Hardness $=50 \times(\mathrm{Ca}+\mathrm{Mg})$ in meq/l $(\mathrm{Hem}, 1989)$

Durfor and Becker (1964) gave the following hardness classification (Tables 12 and 13):

Based on the above classification (Table 12), the groundwater samples of El-Bahariya Oasis can be classified as follows:

\begin{tabular}{lc}
\multicolumn{1}{c}{ Description } & Groundwater samples \% \\
\hline Soft & $5 \%$ \\
\hline Moderately hard & $75 \%$ \\
\hline Hard & $10 \%$ \\
\hline Very hard & $10 \%$
\end{tabular}

Table 12. Hardness classification according to Durfor and Becker (1964)

\begin{tabular}{cc}
\hline Description & Hardness range $\left(\mathbf{m g} / \mathbf{l}\right.$ of $\left.\mathbf{C a C O}_{3}\right)$ \\
\hline S & $0-60$ \\
\hline M.D & $61-120$ \\
\hline H & $121-180$ \\
\hline V.D & $>180$ \\
\hline
\end{tabular}

Table 13. Classification of total Hardness of the ground-water of El-Bahariya Oasis according to Durfor and Becker (1964)

\begin{tabular}{|c|c|c|c|c|c|}
\hline $\begin{array}{l}\text { Well } \\
\text { No. }\end{array}$ & $\begin{array}{l}\text { Total } \\
\text { Hard- } \\
\text { ness }\end{array}$ & $\begin{array}{l}\text { Descri- } \\
\text { ption }\end{array}$ & $\begin{array}{l}\text { Well } \\
\text { No. }\end{array}$ & $\begin{array}{l}\text { Total } \\
\text { Hardness }\end{array}$ & $\begin{array}{l}\text { Descri } \\
- \\
\text { ption }\end{array}$ \\
\hline 1 & 75 & $M D$ & 31 & 102 & $M D$ \\
\hline 2 & 96 & $\mathrm{MD}$ & 32 & 122 & $\mathrm{H}$ \\
\hline 3 & 73 & $\mathrm{MD}$ & 33 & 48 & $\mathrm{MD}$ \\
\hline 4 & 78 & M.D & 34 & 87 & M.D \\
\hline 5 & 95 & $\mathrm{MD}$ & 35 & 239 & $\mathrm{VD}$ \\
\hline 6 & 65 & $\mathrm{MD}$ & 36 & 90 & $M D$ \\
\hline 7 & 87 & $\mathrm{MD}$ & 37 & 70 & $\mathrm{MD}$ \\
\hline 8 & 64 & M.D & 38 & 61 & M.D \\
\hline 9 & 55 & $S$ & 39 & 70 & $\mathrm{MD}$ \\
\hline 10 & 125 & $\mathrm{H}$ & 40 & 81 & $M D$ \\
\hline 11 & 105 & M.D & 41 & 143 & $\mathrm{H}$ \\
\hline 12 & 83 & M.D & 42 & 316 & V.D \\
\hline 13 & 83 & $M D$ & 43 & 115 & $\mathrm{MD}$ \\
\hline 14 & 246 & VD & 44 & 78 & $M D$ \\
\hline 15 & 120 & M.D & 45 & 60 & $S$ \\
\hline 16 & 110 & M.D & 46 & 75 & M.D \\
\hline 17 & 85 & $\mathrm{MD}$ & 47 & 100 & $\mathrm{MD}$ \\
\hline 18 & 130 & $\mathrm{H}$ & 48 & 140 & $\mathrm{H}$ \\
\hline 19 & 70 & M.D & 49 & 112 & M.D \\
\hline 20 & 106 & M.D & 50 & 210 & V.D \\
\hline 21 & 100 & $M D$ & 51 & 100 & $\mathrm{MD}$ \\
\hline 22 & 93 & $\mathrm{MD}$ & 52 & 105 & $M D$ \\
\hline 23 & 85 & M.D & 53 & 95 & M.D \\
\hline 24 & 76 & M.D & 54 & 55 & $S$ \\
\hline 25 & 66 & $M . D$ & 55 & 65 & $M D$ \\
\hline 26 & 135 & $\mathrm{H}$ & 56 & 84 & $M D$ \\
\hline 27 & 90 & M.D & 57 & 118 & M.D \\
\hline 28 & 85 & M.D & 58 & 260 & V.D \\
\hline 29 & 65 & $\mathrm{MD}$ & 59 & 665 & VD \\
\hline 30 & 88 & M.D & & & \\
\hline
\end{tabular}

High total hardness values in the study area may be attributed to over pumping and the effect of leaching and dissolution of salts that increase the solubility of calcium and magnesium in water (Richards, 1954, Freeze and Cherry, 1979, and Hem, 1989). Depending on the interaction of other factors, such as $\mathrm{pH}$ and alkalinity, water with hardness above approximately 200 $\mathrm{mg} / \mathrm{l}$ may cause scale deposition in the distribution system. In contrast, soft water with hardness less than $100 \mathrm{mg} / \mathrm{l}$ has a greater tendency to cause corrosion of pipes (National Research Council, 1977). According to Moustafa et al. (2003), Bahariya Depression may offer opportunities for potential hydrocarbon reserves. Thus, several projects are expected to be established in the future, many of which are petroleum industries. NASNAE, 1972 introduces the quality requirements of water at point of use for some industries, as shown in Table 14. 
Table 14. The quality requirements of water at point of use for some industries according to NAS-NAE (1972)

\begin{tabular}{lccc}
\hline Characters & Paper & Textile & Petroleum \\
\hline $\mathrm{pH}$ & $\ldots$ & $\ldots$. & $6-9$ \\
\hline $\mathrm{TDS}(\mathrm{mg} / \mathrm{l})$ & $200-500$ & $100-200$ & 3500 \\
\hline Alkalinity & $75-150$ & $50-200$ & 500 \\
\hline $\mathrm{Hness}$ & $100-200$ & $0-50$ & 900 \\
\hline $\mathrm{K}+\mathrm{Na}$ & $\ldots$ & $\ldots$ & 230 \\
\hline $\mathrm{Mg}$ & $\ldots$ & $\ldots$ & 85 \\
\hline $\mathrm{SO}$ & $\ldots$. & 100 & 900 \\
\hline $\mathrm{Cl}$ & $0-200$ & 100 & 1600 \\
\hline Silica & $20-100$ & 25 & 85 \\
\hline Iron & $0.1-1.0$ & $0.0-0.3$ & 15 \\
\hline Copper & $\ldots$. & $0.01-5$ & $\ldots$ \\
\hline
\end{tabular}

Based on the above classification (Table 14), the use percent of the groundwater samples of the study area for some industries, can be classified, as follows:

\begin{tabular}{|c|c|c|c|}
\hline & \multicolumn{3}{|c|}{ \% of ground water sample to use } \\
\hline & Paper & Textile & Petroleum \\
\hline pH & $\ldots$ & $\ldots$ & $100 \%$ \\
\hline $\begin{array}{l}\text { TDS } \\
(\mathrm{mg} / \mathrm{l})\end{array}$ & $92 \%$ & $29 \%$ & $100 \%$ \\
\hline Alkalinity & $100 \%$ & $100 \%$ & $100 \%$ \\
\hline Hardness & $90 \%$ & $17 \%$ & $100 \%$ \\
\hline $\mathrm{K}+\mathrm{Na}$ & $\ldots$ & $\ldots$ & $98 \%$ \\
\hline Mg & $\ldots$ & $\ldots$ & $100 \%$ \\
\hline $\mathrm{SO}_{4}$ & $\ldots$. & $88 \%$ & $100 \%$ \\
\hline Cl & $93 \%$ & $75 \%$ & $100 \%$ \\
\hline Silica & $100 \%$ & $93 \%$ & $100 \%$ \\
\hline Iron & $42 \%$ & $20 \%$ & $100 \%$ \\
\hline Copper & $\ldots$ & $100 \%$ & $\ldots$ \\
\hline
\end{tabular}

It can be concluded that the groundwater of ElBahariya Oasis can be used for petroleum and paper industry under ordinary conditions (Abd El-Latif, 2007) but not suitable for textile industry (Serag El-Din, 1999), where high iron contents should be removed prior to use.

\section{REFERENCES}

Abd El-Latif, R.M., 2007. Study of groundwater resources management in Bahariya Oasis. Ph.D. Thesis, Fac. Sci., Alexandria University, 248 pp.

Ali, R., Salama, R., Pollock, D. and Bates, L., 2002. Geochemical interactions between groundwater and soil, groundwater recycling and evaporation in the Oria. (ACIAR) Australian Center For International Agricultural Research, Csiro Land and Water, Perth. Technical Report 21/02, 41pp.

Aydin, M., Yano, T. and Kitamura, Y., 2000. The soil as a natural pool to store rainwater. East Asia 2000 Regional Symposium on Rainwater Utilization. National Taiwan University, Taipei, Taiwan. Proceeding Book, p.93-98.
Aydin, M., Yano, T. and Kilic, S., 2004. Dependence on Zeta potential and soil hydraulic conductivity on adsorbed cation and aqueous phase properties. (SSSAJ) Soil Sci. Soc. Amer. J., V.68, p.450-459.

Ayers, R.S. and Westcot, D.W., 1976. Water Quality for Agriculture. Food and Agriculture Organization of the United Nations, Rome

Barbiéro, L., Valles, V. and Cheverry, C., 2004. Some observations with respect to sodicity hazard of irrigation waters. Agriculture Water Management, V.68, Issue 2, p.177-184.

Bauder, J.W., 2001. Interpretation of chemical analysis of irrigation water and water considered for land spreading. Personal communication. Montana State University, Bozeman, Montana.

Bauder, J.W. and Brock, T.A., 2001. Irrigation water quality, soil amendment, and crop effects on sodium leaching. Arid Land Research and Management,V.15, p.101-113.

Buckman, H.O. and Brady, N.C., 1967. The nature and properties of soils. The MacMillan Company, New York.

Carpenter, A.B., 1978. Origin and chemical evolution of brines in sedimentary basins. In: $13^{\text {th }}$ Industrial Minerals Forum, Johnson, K.S. and Russell, J.R. (eds.), Oklahoma Geological Survey Circular 79, p.78-88.

Chen, Y. and Banin, A., 1975. Scanning electron microscope (SEM) observations of soil structure changes induced by sodium calcium exchange in relation to hydraulic conductivity. Soil Science Society of America Journal,V.120, p.428-436.

Davis, S., Whittemore, D. and Martin, J., 1998. Use of Cl/Br ratios in studies of potable water. J.G.W., V.36, No.2, p.338-350.

Durfor, C.N. and Becker, E., 1964. Public water supplies of the 100 largest cities in the United State. U.S. Geological Survey Water-Supply Paper 1812, 24pp.

Durov, S.A., 1948. Natural waters and graphic representation of their composition. Doklady Akad. Nurak USSR, No.1, p.87-90. (in Russian)

Eaton, F.M., 1950. Significance of carbonates in irrigation waters. Soil Sci., V.69, No.2, p.123-133.

Eckardt, D.A.V. and Stackelberg, P.E., 1995. Relation of groundwater quality to land use on Long Island, New York. Ground Water, V.33, No.6, p.1019-1033.

Edmunds, W.M., 1996. Controls on the geochemistry of sulphur in the east Midlands Triassic aquifer, UK. In: Isotopes in Water Resources Management. IAEA, Vienna, p.107-122.

Edmunds, W.M., Guendouz, A.H., Mamou, A., Moulla, A., Shand, P. and Zouari, K., 2003. Groundwater evolution in the continental Intercalaire aquifer of southern Algeria and Tunisia: trace element and isotopic indicators. Applied Geochemistry, V.18, p.805-825.

Falstad, J., 2000. Soil condition. Transplant Status in Burger Draw. Billings Gazette. Prepared by D.G. Steward Page. Burger Draw Comments and Recommendations. 
FAO, 1985. Guidelines: Land evolution for irrigated agriculture. FAO Soils Bull., 55. FAO, Rome, 321pp.

Cliffs, New Jersey, U.S.A.

Frenkel, H., Goertzen, J.O. and Rhoades, J.D., 1978. Effect of clay type and content, exchangeable sodium percentage, and electrolyte concentration on clay dispersion and soil hydraulic conductivity. Soil Science Society of America Journal. V.142, p.32-39.

Ghabayen, S., McKee, M. and Kemblowski, M., 2006. Ionic and isotopic ratios for identification of salinity sources and missing data in the Gaza aquifer. Journal of Hydrology, V.318, p.360-373.

Giggenbach, W.F., 1988. Geothermal solute equilibria. Derivation of Na-K-Mg-Ca geoindicators. Geochimica et Cosmochimica Acta, V.52, p.2749-2765.

Hall, W.A., 1976. Risk and uncertainty as objectives in water Resources. In: Stochastic Approaches to Water Resources, Proc. on application on Stochastic Method to Water Resources Problems, Shan, N.W. (Editor), Colorado State University, Fort Collins, Colorado, 250pp.

Hanson, B., Grattan, S.R. and Fulton, A., 1999. Agricultural salinity and drainage. University of California Irrigation Program. University of California, Davis.

Hardy, N., Shainberg, I., Gal, M. and Keren, R., 1983. The effect of water quality and storm sequence upon infiltration rate and crust formation. Journal of Soil Science. V.34, p.665-676.

Harsh, S.B., Lloyd, J.W. and Borton, L.R., 1989. Models as an aid to decision making. Acta Hort., V.248, p.27-48.

Hem, J.D., 1989. Study and interpretation of the chemical characteristics of natural water. Third Edition, U.S. Geological Survey, Water Supply Paper 2254, 263pp.

Imaizumi, M., Sukchan, S., Wichaidit, P., Srisuk, K. and Kaneko, F., 2001. Hydrological and geochemical behavior of saline groundwater in Phra Yun, northeast Thailand. JIRCAS Working Report No.30, p.7-14.

(http://ss.jircas.affrc.go.jp:80/kanko/Working\%20Report/No.3 0/30-01-01).

Krug, H., 1989. Growth models as an aid for planning vegetable production in greenhouses. Acta Hort. 260, p.391-400.

Leeden, F.F.L. and Todd, D.K., 1990. The Water Encyclopedia. Lewis Publishers. 808pp.

Magnusdottir, G.Th., Amorsson, S. and Audur, A., 1992. Chemical reaction in upflow zones of geothermal systems affecting subsurface temperature estimates by chemical geothermometry. Water-Rock Interaction, Kharaka and Maest (eds.), Balkema, Rotterdam, p.1459-1462.

Martos, S.F., Bosch, P.A., Sanchez, M.L. and Izquierdo, V.A., 2002. Identification of the origin of salinization in groundwater using minor ions, Lower Andarax, southeast Spain. Sci. Total Environ., V.297, No.(1-3), p.43-58.

Matthess, G., 1982. The properties of groundwater. John Wiley and Sons, New York, 406pp.
McQuillan, R.G. and Spent, P.G., 1976. Addition of chemicals to apartment water supply. Journal of the American Water Works Association, V.68, 415pp.

Mercado, A., 1989. The salinity of groundwater in the BeerSheva Yavqon-Taninim basin. Tahal, Water Planning of Israel, Tel Aviv, Rep. \# 01/08/60 (in Herbrew).

Miller, R.W. and Donahue, R.L., 1995. Soils in our environment. $7^{\text {th }}$ Edition. Prudence Hall, Englewood, Cliffs, NJ. 323pp.

Moustafa, A.R., Saudi, A., Moubasher, A., Mohamed, I., Molokhia, H. and Schwartz, B., 2003. Structural setting and tectonic evolution of El-BahariyaDepression, Western Desert, Egypt. GeoArabia, Gulf Petrolink, Bahrain, V.8, No.1, p.91-124.

National Academy of Sciences and National Academy of Engineering (NAS-NAE), 1972. Water Quality Criteria. Report prepared by committee of Water Quality Criteria at request of U.S. Environmental Protection Agency, Washington, D.C., No.EPA-R373-033, 592pp.

National Research Council (NRC), 1977. Drinking Water and Health. Safe Drinking Water Committee, National Research Council (ISBN 0309026199), V.1, 948pp.

Neal, C. and Kirchner, W., 2000. Sodium and chloride levels in rainfall, mist, stream water and groundwater at the Plynlimon catchments, mid-Wales: inferences on hydrological and chemical controls. Hydrology and Earth System Sciences, V.4, No.2, p.295-310.

Oliman, V.G., 1995. Estudio geoquímico del anillo de Cenotes, Yucatán (Geochemical study of the Ring of Cenotes, Yucatán; in spanish). M.S. Thesis, Instituto de Geofísica, Universidad Nacional Autónoma de México, Mexico City, Mexico, 77 pp.

Perry, E.C., Marin, L.E., McClain, J. and Velazquez, G., 1995. The Ring of Cenotes (sinkholes), northwest Yucatán, Mexico: its hydrogeologic characteristics and possible association with the Chicxulub Impact Crater. Geology, V.23, p.17-20.

Piper, A.M., 1944. A graphic representation in the geochemical interpretation of groundwater analysis. American Geophysical Union Transactions, U.S.A., V.25, p.914-923.

Rainwater, F.H. and Thatcher, L.L., 1960. Methods for collection and analysis of water samples. U.S. Geol. Survey. Water Supply Paper, No.1454, U.S.A.

Richards, L.A., 1954. Diagnosis and improvement of saline and alkali soils. USDA. Handbook No.60, U.S. Govt. Print. Office, Washington, DC., U.S.A.

Richter, B., Dutton, A. and Kreitler, C., 1990. Identification of the sources and mechanisms of salt water pollution affecting groundwater quality: A case study, West Texas. Univ. of Texas, Austin, Texas 78713, 43pp.

Rowe, D.R. and Abdel-Magid, I.M., 1995. Handbook of waste water reclamation and reuse. CRC Press, Inc. 550pp.

Schoeller, H., 1956. Geochemie des eaux souterraines. Application aux eaux des gisements des petrole. Soc. Ed. Techmp, Paris, 213pp. 
Serag El-Din, H., 1999. Hydrochemistry and quality assessment for groundwater of Pre-Cenomanian waterbearing strata in Bahariya Depression, Western Desert, Egypt. Egyptian Journal of Geology, V.43।2, p.269-280.

Sidenvall, J., 1981. Fossil groundwater of marine origin in the Uppsala area, Sweden. Proc. $7^{\text {th }}$ Salt Water Intrusion Meeting, Uppsala, Sweden, p.40-44.

Sprague, R.W., 1972. The geological significance of Boron. U.S. Borax Research Corporation. 58pp.

Starinsky, A., Bielski, M., Ecker, A. and Steinitz, G., 1983. Tracing the origin of salts in groundwater by $\mathrm{Sr}$ isotopic composition (the crystalline complex of the southern Sinai, Egypt). Isot. Geosci., V.1, p.257-267.

Stoessell, R.K. and Carpenter, A.B., 1986. Stoichiometric saturation tests of $\mathrm{NaCl}_{1-\mathrm{x}} \mathrm{Br}_{\mathrm{x}}$ and $\mathrm{KCl}_{1-\mathrm{x}} \mathrm{Br}_{\mathrm{x}}$. Geochimica et Cosmochimica Acta, V.50, p.1465-1474.

Stuyfzand, P.J., 1999. Patterns in groundwater chemistry resulting from groundwater flow. Hydrogeol. J. V.7, p.1527.

Sulin, V.A., 1948. Basis of classification of Natural Waters. Moscow-Leningrad Acad. of Sc., USSR, p.55-67.

Thomas, M.A., 2000. The effect of residential development on groundwater quality near Detroit, Michigan. Journal of the American Water Resources Association, V.36, No.5, p.1023-1038.

Tihansky, D.P., 1974. Economic damages from residential use of mineralized water supply. Water Resources Research, V.10(2), 145pp.

Tyagi, N.K., 2003. Managing saline and alkaline water for higher productivity. Central Soil Salinity Research Institute, CAB International 2003. In: Limits and Opportunities for Improvement, Kijne, J.W., Barker, R. and Molden, D. (eds.), Haryana, India, p.69-88.
www.iwmi.cgiar.org/pubs/Book/CACABI_Series/Water_Prod uctivity/unprotected/0851996698ch5.pdf

Uliana, M.M. and Sharp Jr., J.M., 2001. Tracing regional flow paths to major springs in Trans-Pecos Texas using geochemical data and geochemical models. Chemical Geology, V.179, p.53-72.

U.S.S. Lab. Staff, 1954. Diagnosis and improvement of saline and alkali soils. U.S. Dept. of Agriculture Handbook 60, 160pp.

Van de Graaff, R. and Patterson, R., 2001. Explaining the mysteries of salinity, SAR, and ESP in on-site practice. on-site 01 Available at http://www.lanfixlabs.com.au/papers/p47-mysteries.pdf

Vengosh, A. and Rosenthal, E., 1994. Saline groundwater in Israel: its bearing on the water crisis in the country. J. Hydrol., V.156, p.389-430.

Vengosh, A., Heumann, K.G., Juraski, S. and Kasher, R., 1994. Boron isotope application for tracing sources of contamination in groundwater. Environmental Science Technology, V.28 (11), p.1968-1974.

Vengosh, A., Spivack, A.J., Artzi, Y. and Ayalon, A., 1999. Geochemical and boron, strontium, and oxygen isotopic constraints on the origin of the salinity in groundwater from the Mediterranean coast of Israel. Water Resources Research, V.35 (6), p.1877-1894.

Whittemore, D.O., 1988. Bromide as a tracer in groundwater studies: geochemistry and analytical determination. In: Proceeding of the Groundwater Geochemistry Conference, Denver, CO. National Water Well Assoc., Dublin, oh. P.339-360.

Wilcox, L.V., 1948. The quality of water for irrigation use. U.S. Dept. Agric., Tech. Bull. 962, p.1- 


\section{الملخص العربي}

هيدروجيوكيميائية وحساب جودة المياه الجوفية لحزان الحجر الرملى النوبى فى الواحات البحرية،

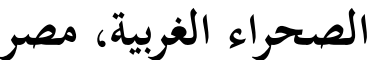

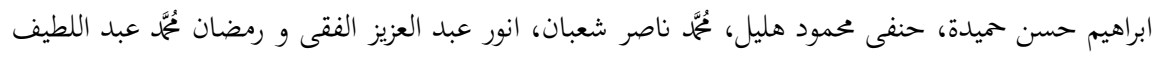

تعتبر المياه الجوفية واحدة من أكثر الموارد الطبيعية الهامة والتي وتعتمد هذه الدراسات على التحليل الكيميائي لعينات المياه المختلفة

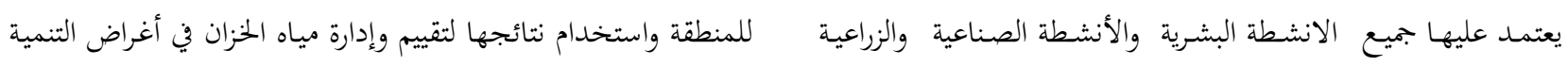

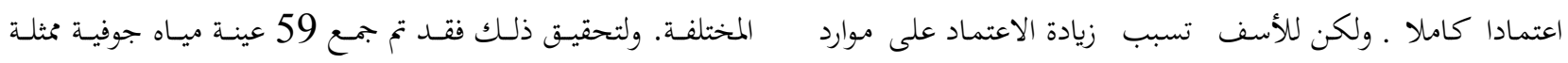

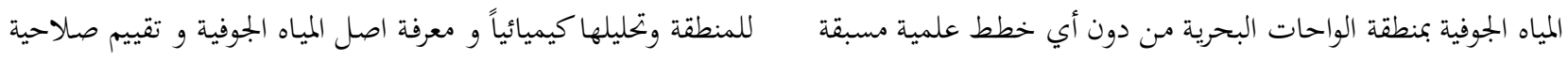

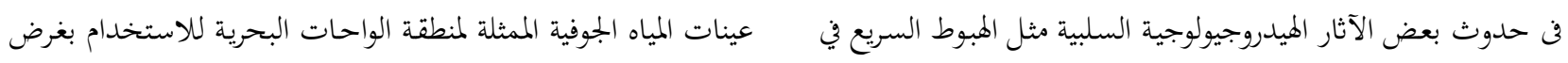

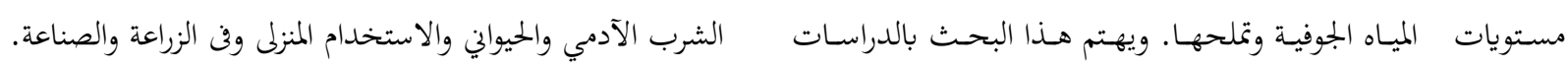
الهيدروجيوكيميائية للمياه الجوفية بمنطقة الدراسة. 